\title{
Ligand-Specific Signaling Profiles and Resensitization Mechanisms of the Neuromedin U2 Receptor
}

\author{
Khaled Alhosaini, ${ }^{1}$ Omar Bahattab, ${ }^{2}$ Heider Qassam, R. A. John Challiss, \\ and Gary B. Willars
}

Department of Molecular and Cell Biology, University of Leicester, Leicester, United Kingdom

Received November 8, 2017; accepted April 24, 2018

\begin{abstract}
The structurally related, but distinct neuropeptides, neuromedin $\mathrm{U}(\mathrm{NmU})$ and neuromedin $\mathrm{S}(\mathrm{NmS})$ are ligands of two G proteincoupled NmU receptors (NMU1 and NMU2). Hypothalamic NMU2 regulates feeding behavior and energy expenditure and has therapeutic potential as an anti-obesity target, making an understanding of its signaling and regulation of particular interest. NMU2 binds both $\mathrm{NmU}$ and $\mathrm{NmS}$ with high affinity, resulting in receptor-ligand co-internalization. We have investigated whether receptor trafficking events post-internalization are biased by the ligand bound and can therefore influence signaling function. Using recombinant cell lines expressing human NMU2, we demonstrate that acute $\mathrm{Ca}^{2+}$ signaling responses to $\mathrm{NmU}$ or $\mathrm{NmS}$ are indistinguishable and that restoration of responsiveness (resensitization) requires receptor internalization and endosomal acidification. The rate of NMU2
\end{abstract}

resensitization is faster following $\mathrm{NmU}$ compared with $\mathrm{NmS}$ exposure, but is similar if endothelin-converting enzyme-1 activity is inhibited or knocked down. Although acute activation of extracellular signal-regulated kinase (ERK) is also similar, activation by NMU2 is longer lasting if NmS is the ligand. Furthermore, when cells are briefly challenged before removal of free, but not receptor-bound ligand, activation of ERK and p38 mitogen-activated protein kinase by $\mathrm{NmS}$ is more sustained. However, only $\mathrm{NmU}$ responses are potentiated and extended by endothelin-converting enzyme-1 inhibition. These data indicate that differential intracellular ligand processing produces different signaling and receptor resensitization profiles and add to the findings of other studies demonstrating that intracellular ligand processing can shape receptor behavior and signal transduction.

\section{Introduction}

The neuropeptide, neuromedin $\mathrm{U}(\mathrm{NmU})$ is widely distributed both in the central nervous system and in the periphery, particularly the gastrointestinal tract. $\mathrm{NmU}$ has been shown to be involved in an array of physiologic and pathologic events, including smooth muscle contraction (Prendergast et al., 2006; Brighton et al., 2008; Mitchell et al., 2009b), thermogenesis, locomotor activity, satiety (Howard et al., 2000; Hanada et al., 2004), glucose homeostasis (Kaczmarek et al., 2006; Peier et al., 2011), inflammatory processes (Johnson et al., 2004; Moriyama et al., 2005, 2006a,b), and cancer (Alevizos et al., 2001; Shetzline et al., 2004; Harten et al., 2011; Rani et al., 2014). NmU mediates these actions via two G protein-coupled receptors (GPCRs), neuromedin U receptor receptors (NMUs)

\footnotetext{
${ }^{1}$ Present address of K.A.: Department of Pharmacology and Toxicology, College of Pharmacy, King Saud University, Riyadh, Kingdom of Saudia Arabia (KSA).

${ }^{2}$ Present address of O.B.: Faculty of Science, Department of Biology, University of Tabuk, Tabuk, Kingdom of Saudia Arabia (KSA).

https://doi.org/10.1124/mol.117.111070.
}

1 and 2 (i.e., NMU1 and NMU2), which are family A GPCRs that share $\sim 50 \%$ homology (Hosoya et al., 2000; Howard et al., 2000; Kojima et al., 2000; Raddatz et al., 2000; Shan et al., 2000; Szekeres et al., 2000). These receptors show distinct patterns of distribution, with NMU1 having a predominantly peripheral distribution and NMU2 being found primarily in the central nervous system, particularly in the hypothalamus, where it plays a key role in the control of appetite, energy expenditure, and circadian rhythm (Mitchell et al., 2009a). Both NMU1 and NMU2 preferentially couple to $\mathrm{G} \alpha_{\mathrm{q} / 11}$ to regulate the activity of phospholipase $\mathrm{C}$, with a number of reports also highlighting $\mathrm{G} \alpha_{\mathrm{i} / \mathrm{o}}$ coupling to inhibit adenylyl cyclase activity (Aiyar et al., 2004; Brighton et al., 2004b).

More recently, neuromedin $\mathrm{S}(\mathrm{NmS})$ has been identified as an alternate endogenous ligand for both NMU1 and NMU2 (Mori et al., 2005; Miyazato et al., 2008) NmS shows a more restricted distribution than $\mathrm{NmU}$, being present primarily in the central nervous system, particularly the suprachiasmatic nucleus of the hypothalamus, where it regulates the circadian rhythm of locomotor activity (Mori et al., 2005). NmU and

ABBREVIATIONS: $\left[\mathrm{Ca}^{2+}\right]_{\text {i }}$, intracellular $\mathrm{Ca}^{2+}$ concentration; Cy3B-pNmU-8, fluorescently labeled porcine neuromedin U-8; ECE-1, endothelinconverting enzyme-1; EGFP, enhanced green fluorescent protein; ERK, extracellular signal-regulated kinase; fluo-4-AM, fluo-4-acetoxymethylester; GPCR, G protein-coupled receptor; HEK, human embryonic kidney; HEK-NMU2, human embryonic kidney 293 cells stably expressing human neuromedin U receptor 2; hNmS-33, human neuromedin S; hNmU-25, human neuromedin U; KHB, Krebs-HEPES buffer; MAPK, mitogen-activated protein kinase; NmS, neuromedin S; NmU, neuromedin $\mathrm{U}$; NMU, neuromedin U receptor; NMU1, neuromedin U receptor 1; NMU2, neuromedin U receptor 2; pERK, phospho-extracellular signal-regulated kinase; p38, p38 mitogen-activated protein kinase; pp38, phospho-p38 mitogenactivated protein kinase; siRNA, short interfering RNA; SM-19712, 4-chloro-N-[[(4-cyano-3-methyl-1-phenyl-1H-pyrazol-5-yl)amino]carbonyl]benzenesulfon amide sodium salt hydrate. 
NmS have generated drug discovery interest, particularly given their abilities to regulate feeding behavior and energy homeostasis. Although peripherally located receptors are able to contribute significantly to these effects (Nakahara et al., 2010; Malendowicz et al., 2012) most attention has been focused on central, hypothalamic actions, where NMU2 is thought to be critical. Thus, intracerebroventricular administration of either $\mathrm{NmU}$ or $\mathrm{NmS}$ reduces feeding behavior in rodents, potentially through regulating hypothalamic corticotropin-releasing hormone release. Interestingly, central administration of $\mathrm{NmS}$ mediates a number of these effects for longer than $\mathrm{NmU}$, including reduced feeding behavior and increases in plasma oxytocin levels (Mori et al., 2005). It has been suggested that a potential explanation for such differences might be a greater resistance to proteolytic degradation of $\mathrm{NmS}$ compared with $\mathrm{NmU}$. Indeed, aside from the absolutely conserved C-terminal heptapeptide in human versions of the two peptides (cf. octapeptide in rat peptides), there is relatively low sequence homology in the remaining $\mathrm{N}$-terminal portions of the peptides, providing ample opportunity for differential interactions and/or degradation by proteases. However, given that there are now many examples of different ligands causing distinct (biased) signaling events at the same GPCR (Thompson et al., 2015; Stott et al., 2016), such alternate possibilities should be considered when taking into account the variation in the responses to centrally administered $\mathrm{NmU}$ and $\mathrm{NmS}$.

Both NmU and NmS bind to their receptors with high affinity (Mitchell et al., 2009b), with an indication that NmS might bind to NMU2 with marginally higher affinity than NmU (Mori et al., 2005). Despite this, in assays of cell signaling, particularly the elevation of intracellular $\mathrm{Ca}^{2+}$ concentration $\left(\left[\mathrm{Ca}^{2+}\right]_{\mathrm{i}}\right), \mathrm{NmU}$ and $\mathrm{NmS}$ show equivalent potency and intrinsic activity at both NMU1 and NMU2 (Mitchell et al., 2009b). However, assessment of transient $\mathrm{Ca}^{2+}$ signals might not reflect the full extent of the signaling pathways activated by these receptors, including any additional complexities of receptor regulation and signaling bias displayed by the different endogenous ligands. In the present study, we have explored signaling and receptor regulation in response to NmU and NmS at NMU2 and demonstrate key differences between these two endogenous ligands that are of potential physiologic and therapeutic importance.

\section{Materials and Methods}

Materials. Minimum essential medium with Earle's salts, fetal bovine serum, Dulbecco's phosphate-buffered saline without calcium and magnesium, penicillin $(10,000 \mathrm{U} / \mathrm{ml})$, and streptomycin $(10,000 \mu \mathrm{g} / \mathrm{ml})$ were obtained from Fisher Scientific (Loughborough, United Kingdom). Pluronic acid F-127 was obtained from Molecular Probes (Eugene, OR). Bovine serum albumin, poly-D-lysine, fluo-4acetoxymethylester (fluo-4-AM), cycloheximide, monensin, dynasore, 4-chloro-N-[[(4-cyano-3-methyl-1-phenyl-1H-pyrazol-5-yl)amino]carbonyl]benzenesulfon amide sodium salt hydrate (SM-19712), and carbachol were obtained from Sigma-Aldrich (Poole, United Kingdom). Human neuromedin U (hNmU-25) and human $\mathrm{NmS} \mathrm{(hNmS-33)}$ were purchased from Bachem (St. Helens, United Kingdom). Fluorescently labeled porcine NmU-8 (Cy3B-pNmU-8) was a kind gift from GlaxoSmithKline (Harlow, UK). Polyvinylidene fluoride membrane was purchased from Millipore (UK) Ltd. (Watford, United Kingdom). Prestained protein ladders were obtained from Fermentas (Leon-Rot, Germany). Greiner ELISA 96-well plates (eight well/strip) were obtained from Scientific Laboratory Supplies Ltd. (Nottingham, United Kingdom). Rabbit monoclonal phospho-p44/42 mitogen-activated protein kinases [(MAPKs), extracellular signal-regulated kinase (ERK) 1/2] (Thr202/Tyr204) antibody, rabbit polyclonal p42 MAPK (ERK2) antibody, rabbit monoclonal S6 ribosomal protein antibody, rabbit polyclonal phospho-p38 MAPK (p38) (Thr180/Tyr182), and horseradish peroxidase-linked anti-rabbit IgG secondary antibody were obtained from New England Biolabs (UK) Ltd. (Hitchin, United Kingdom). Rabbit IgG polyclonal anti-endothelin-converting enzyme-1 antibody (GTX113676) was obtained from GeneTex (Irvine, CA). OptiLight chemiluminescent substrate solution was purchased from Cheshire Sciences (UK) Ltd. (Chester, United Kingdom). The pEGFP-N1 plasmid, containing the coding sequence for enhanced green fluorescent protein (EGFP), was purchased from Clontech (Oxford, United Kingdom). Lipofectamine RNAiMAX for transfection of short interfering RNA (siRNA) was purchased from Invitrogen (Paisley, United Kingdom). ON-TARGET plus SMART pool consisting of four distinct siRNA duplexes of siRNA targeted to human endothelin-converting enzyme-1 (ECE-1) mRNA and the scrambled siRNA were obtained from ThermoFisher Scientific (Waltham, MA) and Invitrogen, respectively.

Cell Culture. Human embryonic kidney (HEK) 293 cells with stable expression of human NMU2 (HEK-NMU2) have been described and characterized previously (Brighton et al., 2004b). Cells were cultured in minimal essential medium with Earle's salts, supplemented with fetal bovine serum $(10 \% \mathrm{v} / \mathrm{v})$, penicillin, and streptomycin ( $1 \% \mathrm{v} / \mathrm{v}$ of purchased stocks), and grown in $75 \mathrm{~cm}^{2}$ flasks maintained in a humidified environment of $95 \%$ air and $5 \% \mathrm{CO}_{2}$ at $37^{\circ} \mathrm{C}$. Cultures were passaged every 3-5 days, or as required for experiments.

Measurement of Changes in Intracellular $\mathrm{Ca}^{2+}$ Concentration. Changes in $\left[\mathrm{Ca}^{2+}\right]_{\mathrm{i}}$ were monitored in either single cells by confocal microscopy or in cell populations using a NOVOstar plate reader (BMG Labtech, Ortenberg, Germany). For imaging experiments, cells were cultured on 25-mm-diameter coverslips for 24-48 hours to approximately $60 \%$ confluence and then loaded with the fluorescent $\mathrm{Ca}^{2+}$ indicator fluo- 4 by incubation for 45 minutes at $37^{\circ} \mathrm{C}$ in Krebs-HEPES buffer (KHB) (118 mM NaCl, $4.7 \mathrm{mM} \mathrm{KCl}, 10 \mathrm{mM}$ HEPES, $11.7 \mathrm{mM}$ glucose, $1.2 \mathrm{mM} \mathrm{MgSO}_{4}, 4.2 \mathrm{mM} \mathrm{NaHCO}_{3}, 1.2 \mathrm{mM}$ $\mathrm{KH}_{2} \mathrm{PO}_{4}, 1.3 \mathrm{mM} \mathrm{CaCl}$, bovine serum albumin $0.1 \% \mathrm{w} / \mathrm{v}, \mathrm{pH} 7.4$ ) containing fluo-4-AM $(2 \mu \mathrm{M})$ and pluronic acid F-127 $(0.036 \%$, w/v). Following a brief wash, the coverslips were mounted to form the base of a perfusion chamber and KHB $(450 \mu \mathrm{l})$ was added. Images were taken using an Olympus inverted microscope with a $60 \times$ oil immersion lens and a PerkinElmer UltraVIEW confocal imaging system [PerkinElmer LAS (UK) Ltd., Beaconsfield, United Kingdom] using a laser excitation wavelength of $488 \mathrm{~nm}$ and emitted light collected at wavelengths $>510 \mathrm{~nm}$. Images were collected at a rate of approximately 1 frame $s_{-1}$ with an exposure multiplier of 1 , exposure times of $\sim 200$ milliseconds, and either $1 \times 1$ or $2 \times 2$ binning. Minimum and maximum levels of the gray scales of images were adjusted between 0 and approximately 1000 against a full scale of 4096. Temperature was maintained at $37^{\circ} \mathrm{C}$ by a Peltier unit (Harvard Applications Inc., Kent, United Kingdom). Basal images were taken at least 30 seconds before bath addition of agonist. The change in fluorescence was recorded within a cytosolic region of interest using UltraVIEW 4.0 software and analyzed as an index of $\left[\mathrm{Ca}^{2+}\right]_{\mathrm{i}}$ relative to the basal levels. In experiments where repetitive agonist additions were made, washes between additions were performed by perfusion of the cells with KHB ( $5 \mathrm{ml} / \mathrm{min})$. During these experiments, agonist additions were made after ensuring that the focus was stable and no further adjustments were made. Recording in the interval between agonist additions was stopped to avoid photobleaching. In resensitization experiments where the recovery period was $>45$ minutes, initial stimulation was performed on unloaded cells that were subsequently loaded with fluo- 4 during the last 45 minutes of the experiment prior to measurement of $\left[\mathrm{Ca}^{2+}\right]_{\mathrm{i}}$. The $\mathrm{Ca}^{2+}$ signaling experiments were performed at $37^{\circ} \mathrm{C}$.

For cell population studies, cells were plated in poly-D-lysine-coated 8 -well strips of a 96 -well plate format for 24 hours. On the day of the 
experiments, growth medium was aspirated and the cells were washed twice with KHB and loaded with fluo-4-AM as described previously. Cells were then washed once with KHB and incubated with $100 \mu \mathrm{l} \mathrm{KHB}$ at $37^{\circ} \mathrm{C}$ for 5 minutes. Using the NOVOstar plate reader, changes in fluorescence were then determined as an index of changes in $\left[\mathrm{Ca}^{2+}\right]_{\mathrm{i}}$. Automated additions were of $20 \mu \mathrm{l}$ made at a speed of $230 \mu \mathrm{l} / \mathrm{s}$. In protocols in which $\mathrm{Ca}^{2+}$ signaling by NMU2 was used to examine desensitization and resensitization, the initial challenge was performed manually using the same volume as in the automated additions. In these experiments, the 45-minute loading of fluo-4-AM and 5-minute postloading incubation were always in the 50 minutes immediately prior to the measurement of $\mathrm{Ca}^{2+}$ signaling. Where required, the equation $\left[\mathrm{Ca}^{2+}\right]_{\mathrm{i}}=K_{\mathrm{d}} \times\left(F-F_{\min }\right) /\left(F_{\max }-F\right)$ was used to convert measurements of fluo-4 fluorescence $(F)$ in populations of cells into $\left[\mathrm{Ca}^{2+}\right]_{\mathrm{i}}$, where the $K_{\mathrm{d}}$ value of fluo-4-AM was taken as $350 \mathrm{nM}$ (Yamasaki-Mann et al., 2009). Maximal fluorescence $\left(F_{\max }\right)$ was determined by the addition of ionomycin $(2 \mu \mathrm{M})$ and $4 \mathrm{mM} \mathrm{Ca}^{2+}$ to selected wells for up to 10 minutes. Minimal fluorescence $\left(F_{\min }\right)$ was then obtained by replacing the buffer with $150 \mu \mathrm{l}$ of $\mathrm{Ca}^{2+}$-free buffer containing $2 \mathrm{mM}$ EGTA for up to 10 minutes.

Chemical Treatments in Resensitization Experiments. All of the chemical interventions in the resensitization experiments were begun 30-60 minutes (stated in Results) prior to the first challenge with agonist (desensitizing challenge) and continued throughout all subsequent experimental steps, unless otherwise stated.

Imaging Cy3B-pNmU-8 Binding to HEK-NMU2. Cy3B-pNmU-8 binding to HEK-NMU2 was visualized using confocal microscopy with an excitation wavelength of $568 \mathrm{~nm}$. Briefly, cells were cultured on poly-D-lysine-coated 25-mm-diameter glass coverslips for 24-48 hours. Cells were then washed with KHB, the coverslips were mounted to form the base of a perfusion chamber, and KHB $(450 \mu \mathrm{l})$ added. Direct bath addition of Cy3B-pNmU-8 (10 nM final concentration) was performed and images taken using the Olympus inverted microscope with a $60 \times$ oil immersion lens and a PerkinElmer UltraVIEW confocal imaging system. Cells were excited using a $\mathrm{Kr} / \mathrm{Ar}$ laser at a wavelength of $568 \mathrm{~nm}$ and emission was collected with a broad band red-green-blue filter. Temperature was maintained at $37^{\circ} \mathrm{C}$ by the Peltier unit. For experiments where long washing periods were required or a different $\mathrm{pH}$ buffer was used, cells were perfused at $5 \mathrm{ml} / \mathrm{min}$ using the appropriate buffer.

Receptor and Ligand Internalization. The cDNA encoding human NMU2 was inserted into the pEGFP-N1 plasmid to allow expression of NMU2 with a C-terminal EGFP tag. HEK293 cells were transfected and a stable cell line was selected. NMU2-EGFPexpressing cells were cultured on glass coverslips for confocal microscopy imaging of NMU2-EGFP using 488-nm excitation (as previously described). For dual confocal imaging of NMU2-EGFP and Cy3B-pNmU-8, cells were imaged alternately with 488 and $568 \mathrm{~nm}$ excitation as described previously. Internalization of NMU2EGFP was quantified using the open source, image processing program, ImageJ. For individual cells, fluorescence intensity was measured at a region of the plasma membrane and within the cytosolic compartment. After subtraction of background fluorescence calculated from regions of the images lacking cells, a measure of internalization was derived using the following equation: internalization $=1-\left(\mathrm{Fm}_{t} /\right.$ $\left.\mathrm{Fc}_{t}\right) /\left(\mathrm{Fm}_{b} / \mathrm{Fc}_{b}\right)$, where $\mathrm{Fm}$ is the membrane fluorescence, $\mathrm{Fc}$ is the cytoplasmic fluorescence, and $t$ is time (of measurement); $\mathrm{Fm}_{b}$ and $\mathrm{Fc}_{b}$ represent these parameters under basal $(b)$ conditions at the start of the experiment ( 0 minutes).

Knockdown of ECE-1 Expression. For ECE-1 knockdown, cells were plated into poly-D-lysine-coated 24 -well plates and left to attach for 5 to 6 hours (50\%-60\% confluence). The medium was replaced with Opti-MEM (without serum; $500 \mu \mathrm{l} /$ well) (Gibco; Thermo Fisher Scientific). Lipofectamine RNAiMAX Reagent was diluted in Opti$\operatorname{MEM}(3: 50 \mathrm{v} / \mathrm{v})$ and another equal volume of Opti-MEM containing an appropriate amount of either siRNA against ECE-1 or a scrambled version (10 pmol/well) was prepared. The diluted siRNA was then added into the diluted reagent $(1: 1 \mathrm{v} / \mathrm{v})$. After 20 -minute incubation at room temperature, the siRNA complex was added into each well $(100 \mu \mathrm{l})$. After approximately 16-hour incubation, the medium was replaced with fresh complete medium. The cells were used 48 hours after transfection. Knockdown of ECE-1 was confirmed by immunoblotting with an anti-ECE-1 antibody (1:1000), using immunoblotting with an antibody against total ERK (1:1000) as a loading control using the protocol described subsequently.

Determining ERK and p38 MAPK Activity. The activation of ERK and p38 MAPK were determined by immunoblotting of phosphoERK (pERK) and phospho-p38 MAPK (pp38), respectively. Cell monolayers on poly-D-lysine-coated 24 -well plates were serum starved overnight and then washed and equilibrated with KHB at $37^{\circ} \mathrm{C}$. An appropriate concentration of agonist was then added and cells were incubated for the indicated times. In cases where SM-19712 was used, this was added 30 minutes prior to agonist challenge unless stated otherwise and left in place through subsequent manipulations. Incubations were terminated by aspiration and addition of ice-cold solubilization/sample buffer [125 mM Tris-base, $1 \mathrm{mM} \mathrm{Na}_{3} \mathrm{VO}_{4}, 10 \%$ (w/v) SDS; $50 \%$ (v/v) glycerol; $0.01 \%$ (w/v) bromophenol blue; $250 \mathrm{mM}$ dithiothreitol, adjusted to $\mathrm{pH}$ 6.8]. Cell lysates were sonicated with an ultrasonic cell disruptor (Sonifier, Branson, CT) for 2 seconds at $10 \%$ of

A
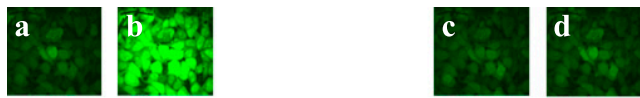

hNmU-25 $\quad$ Wash, KHB, pH 7.4 $\quad$ hNmU-25
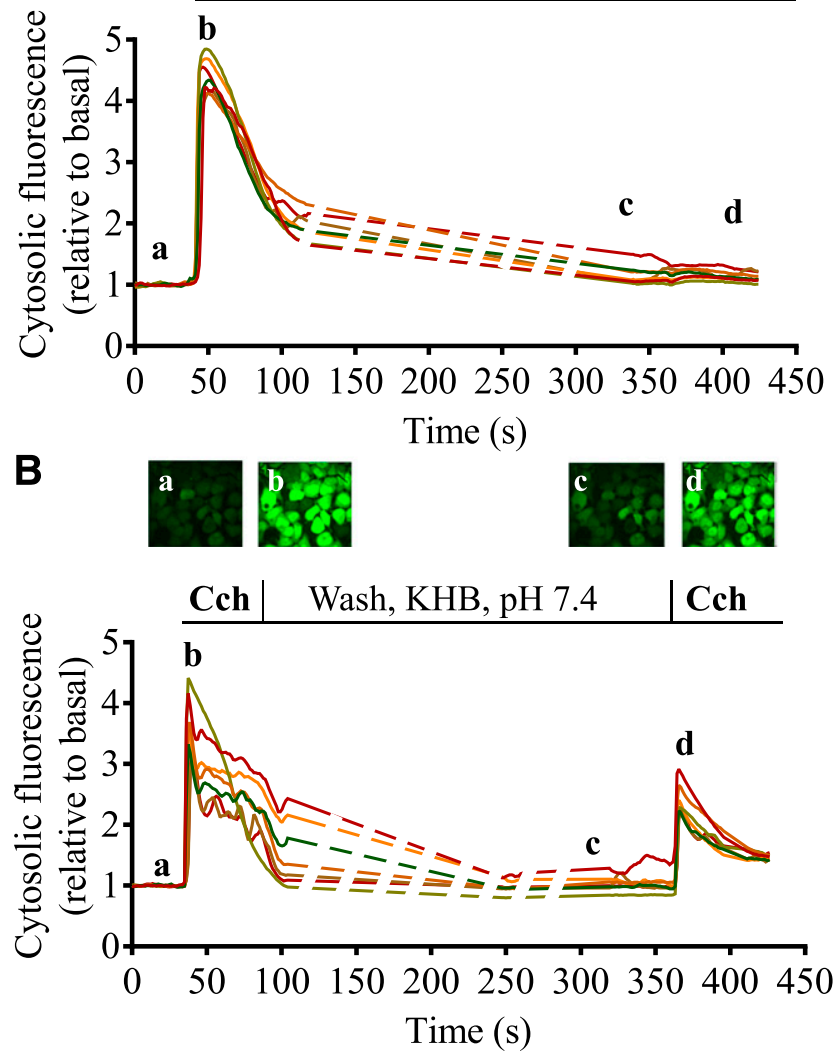

Fig. 1. $\mathrm{Ca}^{2+}$ responses in HEK-NMU2 to applications of either hNmU-25 or carbachol. Cells were loaded with fluo-4-AM and changes in cytosolic fluorescence intensity were measured as an index of $\left[\mathrm{Ca}^{2+}\right]_{\mathrm{i}}$ using confocal microscopy. Cells were challenged with either $(\mathrm{A}) \mathrm{hNmU}-25(30 \mathrm{nM})$ or $(\mathrm{B})$ carbachol $[(\mathrm{Cch})$, $300 \mu \mathrm{M}]$ at $t=30$ seconds for 60 seconds. Cells were then perfused with KHB, and after 5 minutes the same ligand was reapplied to the cells. Changes in fluo4 fluorescence are shown relative to the basal level. The dashed lines indicate where data were not collected. Each line represents data from a single cell and each representative image $(\mathrm{a}-\mathrm{d})$ was taken at the points indicated on the timecourse graph. Data are representative of three separate experiments, with at least five cells observed in each experiment. 
maximal power and then centrifuged $\left(12,000 \mathrm{~g}\right.$ for 10 minutes at $\left.4^{\circ} \mathrm{C}\right)$. Supernatants were either used immediately or stored at $-80^{\circ} \mathrm{C}$ until use.

Proteins were separated by SDS-PAGE using a 10\% resolving gel and transferred onto polyvinylidene fluoride membranes. Following blocking of the membrane for 1 hour at room temperature in Tween-20 buffer [Tris-buffered saline/Tween 20: $50 \mathrm{mM}$ Tris-base, $\mathrm{pH}$ 7.5; $150 \mathrm{mM} \mathrm{NaCl}$; $0.05 \%(\mathrm{v} / \mathrm{v})$ Tween-20] containing $5 \%$ bovine serum albumin, membranes were probed overnight at $4^{\circ} \mathrm{C}$ using either rabbit monoclonal phospho-p44/42 MAPK (pERK1/2) antibody (1:2000), pp38 (1:1000), or rabbit monoclonal S6 ribosomal protein antibody (1:20,000). Following washing, membranes were incubated in Tris-buffered saline/Tween 20 with $5 \%(\mathrm{w} / \mathrm{v})$ fat-free milk containing goat anti-rabbit IgG and horseradish peroxidase-linked secondary antibody (1:3000) for 60 minutes at room temperature. Detection was performed by applying the OptiLight chemiluminescent reagent. Using ribosomal S6 band intensities, loading was assessed to be equivalent before analysis of the band intensities of the phospho-proteins. To allow direct comparison of band intensities, all samples for each experimental replicate in which the effects of hNmU-25 and hNmS-33 in the presence and absence of the ECE-1 inhibitor (SM-19712) were to be compared were run together and ultimately exposed on the same piece of film.

Data Analysis. Data were analyzed using Prism software (version 7.0; GraphPad Software Inc., San Diego, CA) and expressed as mean \pm S.E.M. unless otherwise stated. Where representative data are shown, these are of at least three independent experiments. To construct concentration-response curves for agonist-mediated changes in $\left[\mathrm{Ca}^{2+}\right]_{\mathrm{i}}$, the maximal changes in fluorescence were subtracted from the basal values. Concentration-response curves were fit for each experiment using a four-parameter logistical equation to allow determination of individual maximal values $\left(E_{\max }\right)$ and $\mathrm{pEC}_{50}$ values $\left(-\log _{10} \mathrm{M} \mathrm{EC}_{50}\right)$ for any subsequent descriptive or comparative statistical analyses: curves of the mean data of all experiments are displayed in Figures 3 and 5. For measuring the recovery of either $\mathrm{Ca}^{2+}$ concentration-response curves or maximal $\mathrm{Ca}^{2+}$ responses, changes in fluorescence were expressed as a percentage of the maximum response in cells pre-exposed to buffer only (i.e., no initial agonist challenge). All statistical analyses were performed on the raw data before normalization. In recovery experiments, for each recovery time point, a control/response was also measured. Comparative statistics were performed using one-way analysis of variance, followed by an appropriate range test, with $P<0.05$ considered significant.

\section{Results}

Single-Cell $\mathrm{Ca}^{2+}$ Responses to hNmU-25. Confocal fluorescence imaging of adherent, fluo-4-loaded HEK-NMU2 cells demonstrated a rapid, transient elevation of $\left[\mathrm{Ca}^{2+}\right]_{\mathrm{i}}$ following addition of hNmU-25 (30 nM) (Fig. 1A). To examine NMU2 desensitization, cells were perfused for 5 minutes with KHB following an initial 60 -second challenge with hNmU-25. Reapplication of hNmU-25 failed to evoke any increase in $\left[\mathrm{Ca}^{2+}\right]_{\mathrm{i}}$ (Fig. 1A), consistent with our previous findings (Brighton et al., 2004b). In contrast, employing a similar protocol, we could demonstrate partial desensitization $(40 \% \pm 2 \%$ of initial response) of an endogenous $\mathrm{M}_{3}$ muscarinic acetylcholine receptor when measuring $\left[\mathrm{Ca}^{2+}\right]_{\mathrm{i}}$ responses (Fig. 1B).

Developing a Protocol to Remove Completely CellBound Ligand. Our previous studies demonstrated that $\mathrm{NmU}$ binding to NMU receptors is essentially irreversible (Brighton et al., 2004b). To examine whether the observed functional desensitization of NMU2 $\mathrm{Ca}^{2+}$ signaling was altered by ligand removal, we developed a protocol to dissociate ligand from cell-surface receptors, without compromising $\mathrm{Ca}^{2+}$ signaling or cell viability (described subsequently). Using confocal imaging of Cy3B-pNmU-8, we have shown that a rapid acidwash procedure removes cell-bound $\mathrm{NmU}$ without negatively impacting receptor-mediated $\mathrm{Ca}^{2+}$ signaling or cell viability. Thus, addition of Cy3B-pNmU-8 to NMU2 resulted in intense membrane-localized fluorescence that was unaffected by subsequent perfusion with standard KHB (pH 7.4) (Fig. 2A, images $\mathrm{i}$ and ii). Perfusion for 15-25 seconds with acidic KHB solutions at pH 4.0 (Fig. 2A, image iii), pH 3.5 (Fig. $2 \mathrm{~A}$, image iv), or pH 3.0 (Fig. 2A, image v) failed to displace membrane fluorescence; however, exposure to $\mathrm{pH} 2.0$ completely removed membrane fluorescence (Fig. 2A, image vi). Fluorescence was not restored by a 5 -minute wash with standard KHB, indicating ligand removal rather than quenching of fluorescence (Fig. 2B, images i-iii). Moreover, reapplication of Cy3B-pNmU-8 to these cells restored membrane fluorescence (Fig. $2 \mathrm{~B}$, images iv), indicating that NMU2 was able to rebind ligand.

To determine whether the brief acid wash influenced receptor-mediated $\mathrm{Ca}^{2+}$ signaling, HEK-NMU2 cells were first washed briefly ( $\leq 25$ seconds) with $\mathrm{KHB}$ at either $\mathrm{pH}$ 2.0 or 7.4, followed by either a 5- or 120-minute period in KHB (pH 7.4) before determining $\mathrm{Ca}^{2+}$ responses. The brief wash with acidified buffer did not affect $\mathrm{hNmU}-25$-mediated $\mathrm{Ca}^{2+}$ responses in ligand-naive cells $\left(\mathrm{pEC}_{50}\right.$ values: $9.17 \pm 0.02$
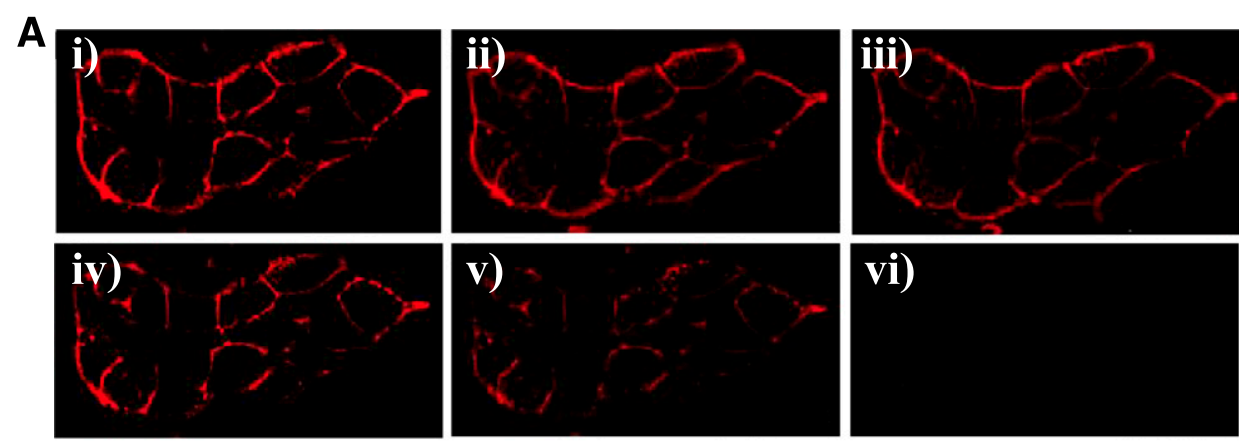

B
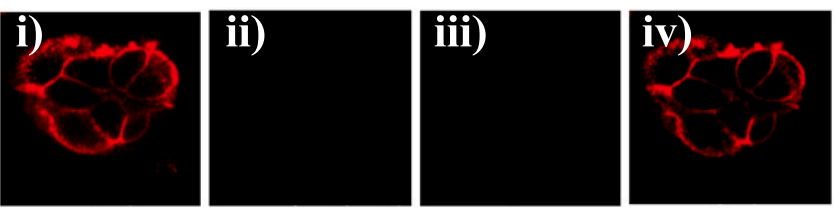

Fig. 2. Visualizing ligand binding and the removal of ligand bound to NMU2. HEKNMU2 cells were challenged with the fluorescently labeled $\mathrm{NmU}$ ligand, Cy3B-pNmU-8 $(10 \mathrm{nM})$ and visualized by confocal microscopy. Image $\mathrm{i}$ in (A) shows fluorescence directly after addition of Cy3B-pNmU-8. Cells were then washed with $\mathrm{KHB}(5 \mathrm{ml} / \mathrm{min}) \mathrm{pH} 7.4(\mathrm{~A}$, image ii), followed by a brief 30 -second wash with KHB at $\mathrm{pH} 4$ (A, image iii), $\mathrm{pH} 3.5$ (A, image iv), $\mathrm{pH}$ 3.0 (A, image v), or $\mathrm{pH} 2.0$ (A, image vi). Image i in (B) shows fluorescence 60 seconds after addition of Cy3B-pNmU-8 (10 nM) and immediately following a brief wash ( $\leq 25$ seconds) with $\mathrm{KHB}$ at $\mathrm{pH} 2.0$ (B, image ii). Further images were taken after perfusion with $\mathrm{KHB}$ $\mathrm{pH} 7.4(5 \mathrm{ml} / \mathrm{min})$ for 5 minutes (B, image iii) or following reapplication of Cy3B-pNmU-8 (B, image iv). Temperature was maintained at $12^{\circ} \mathrm{C}$ to prevent receptor internalization. Images are representative of at least three experiments where similar results were obtained. 
and $9.18 \pm 0.10$ with $\mathrm{KHB}, \mathrm{pH} 2.0$, wash and 5 - or 120 -minute recovery, respectively; $9.43 \pm 0.08$ and $9.16 \pm 0.11$ with $\mathrm{KHB}$, pH 7.4, wash and 5- or 120-minute recovery, respectively) (Fig. 3, A and B). Furthermore, cell viability, as assessed by confocal imaging of trypan blue exclusion, was unaffected by the wash with acidified KHB (cell viability $89 \% \pm 5 \%$ at 30 minutes following acid wash compared with $90 \% \pm 7 \%$ following wash with $\mathrm{KHB}, \mathrm{pH} 7.4)$. However, extending the wash with $\mathrm{KHB}, \mathrm{pH} 2.0$, to 45-55 seconds did have a marked detrimental effect on cell viability $(34 \% \pm 5 \%)$.

Functional Desensitization of NMU2. Having established a wash procedure that removes surface-bound ligand, but retains receptor-mediated $\mathrm{Ca}^{2+}$ signaling and cell viability, this protocol was next used to explore NMU2 desensitization in the absence of ligand bound to cell-surface receptors. When fluo-4-loaded HEK-NMU2 cells were challenged with hNmU-25 (30 nM, 60 seconds), followed by a brief wash with acidic buffer (KHB, $\mathrm{pH} 2.0 ; \leq 25$ seconds) and reperfusion with normal buffer (KHB, pH 7.4; 5 minutes), reapplication of hNmU-25 (30 nM) now resulted in a $\mathrm{Ca}^{2+}$ response that was $56 \% \pm 8 \%$ of the initial agonist-stimulated response $(n=3$, Fig. 3C). In the same series of experiments using carbachol instead of $\mathrm{hNmU}-25$, the $\mathrm{Ca}^{2+}$ response to the rechallenge with carbachol was $39 \% \pm 8 \%$ of the initial response $(n=3$; Fig. 3D), similar to the extent of $\mathrm{M}_{3}$ muscarinic acetylcholine receptor desensitization observed previously (Fig. 1B).

Resensitization in the Absence or Continuing Presence of Extracellular Ligand. To assess the impact of the duration of ligand exposure on the subsequent desensitization, HEK-NMU2 cells were exposed to a maximally effective concentration of hNmU-25 (30 $\mathrm{nM})$ for $1,3,5$, or 30 minutes. Ligand was then removed with a brief $\mathrm{KHB}, \mathrm{pH} 2.0$, wash and subsequent washing with $\mathrm{KHB}, \mathrm{pH} 7.4$; cells were then allowed to recover for 5 minutes before rechallenge with
A

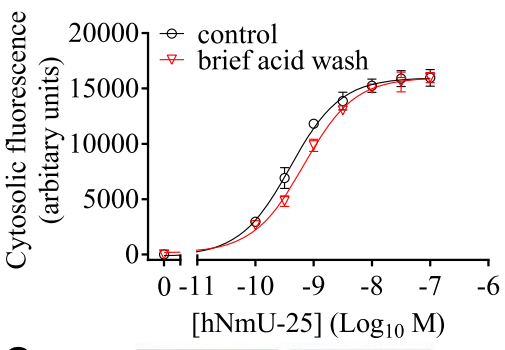

c

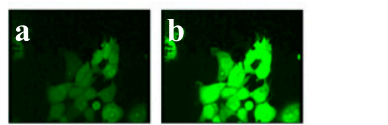

B
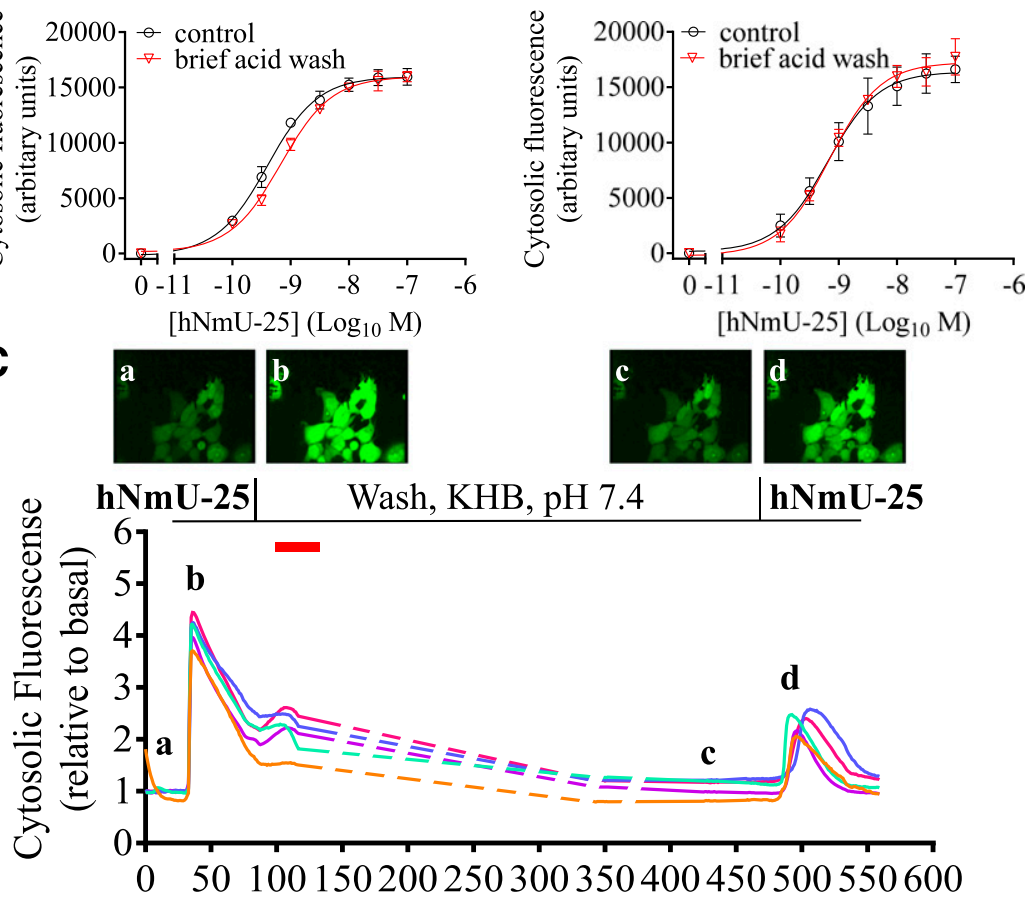

D
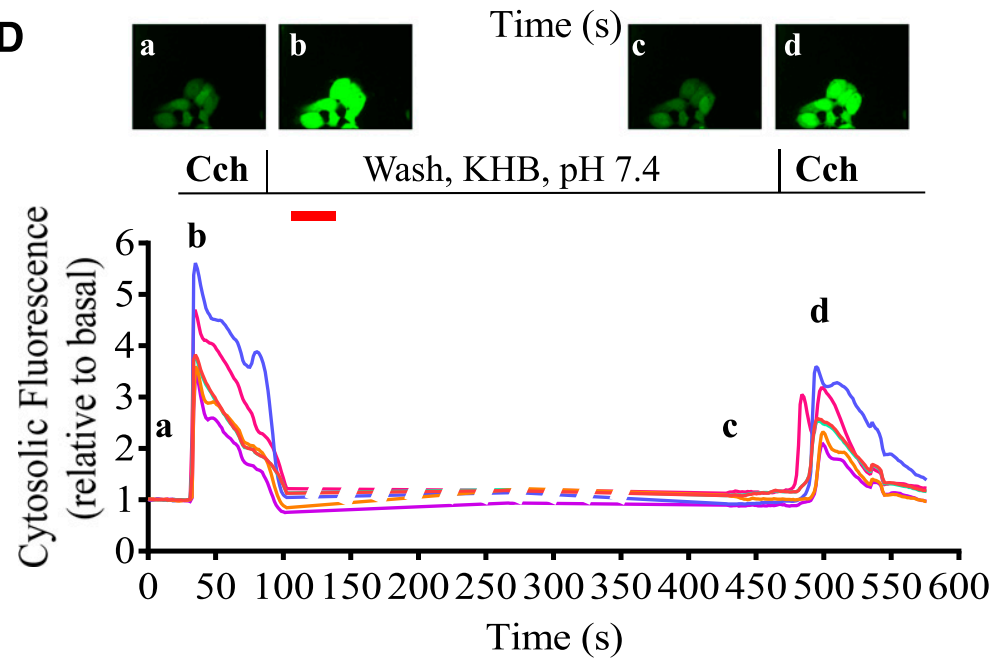

Fig. 3. $\mathrm{Ca}^{2+}$ responses in HEK293-NMU2 are unaltered by brief acid washing. For a 5-minute recovery period (A) HEKNMU2 cells were loaded with fluo-4-AM and then exposed to a brief wash ( $\leq 25$ seconds) with KHB at either $\mathrm{pH} 7.4$ or 2.0 , followed by three washes with $\mathrm{KHB}(\mathrm{pH}$ 7.4). Cells were then challenged with hNmU-25 and changes in fluorescence intensity were measured as an index of $\left[\mathrm{Ca}^{2+}\right]_{\mathrm{i}}$. For the 2-hour recovery period (B), cells were washed as previously described, but loaded with fluo-4-AM during the last 45 minutes of the 2-hour recovery period. For either recovery period, maximal changes in fluorescence following hNmU-25 challenge were determined and used to construct concentration-response curves. Data are mean \pm S.E.M., $n=3$. For imaging experiments, fluo-4-AM-loaded cells were challenged with either (C) hNmU-25 (30 $\mathrm{nM})$ or (D) carbachol [(Cch), $300 \mu \mathrm{M})$ at $t=30$ seconds for 60 seconds. Cells were then perfused briefly ( $\leq 20$ seconds) with KHB pH 2.0 followed by perfusion with $\mathrm{KHB} \mathrm{pH}$ 7.4, and after approximately 6 minutes the same ligand was used to rechallenge the cells. The dashed lines indicate periods when data were not collected. Each line represents data from a single cell and each representative image $(a-d)$ was taken at the points indicated on the time-course graph. Data are representative of three separate experiments, with at least five cells observed in each experiment. 
the same concentration of hNmU-25 (Fig. 4A). A rapid, progressive reduction in the $\mathrm{Ca}^{2+}$ response to rechallenge was observed as the duration of the initial challenge was increased from 1 to 5 minutes (Fig. 4B), while increasing the duration of the initial challenge from 5 to 30 minutes did not further reduce the response to $\mathrm{hNmU}-25$ rechallenge (Fig. 4, $\mathrm{B}$ and $\mathrm{C}$ ).

To determine 1) the time course of receptor resensitization and 2) the effect of ongoing ligand binding to NMU2, cells were challenged with a maximal concentration of hNmU-25 (30 $\mathrm{nM})$ for 5 minutes and then washed with either KHB, pH 2.0, or $\mathrm{KHB}, \mathrm{pH}$ 7.4. Following recovery periods of 5-360 minutes in
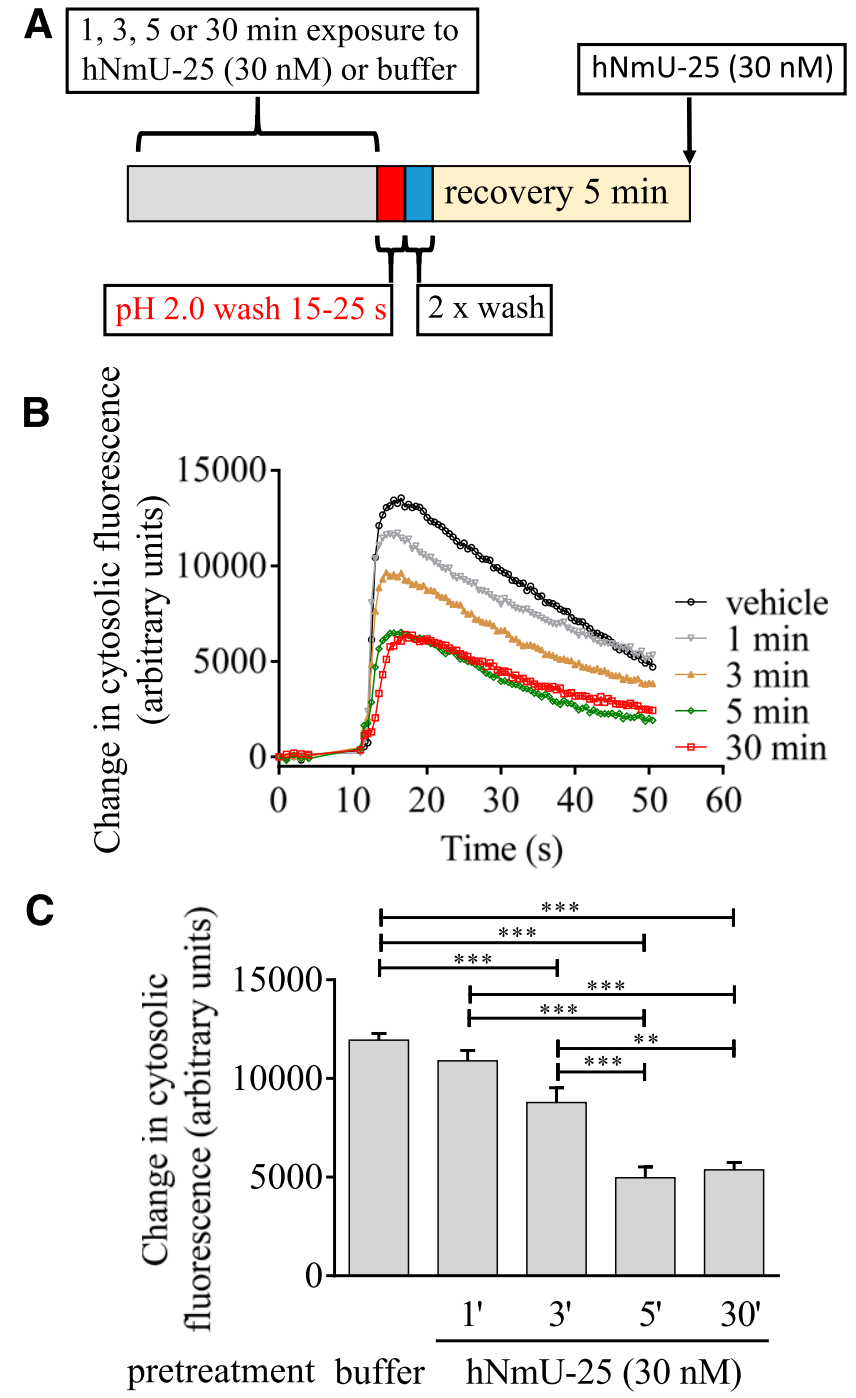

Fig. 4. Effect of the duration of pre-exposure to hNmU-25 on homologous desensitization of NMU2. HEK-NMU2 cells were loaded with fluo-4-AM and challenged with either buffer or hNmU-25 (30 nM) for $1,3,5$, or 30 minutes. Following the initial agonist challenge, cells were briefly washed ( $\leq 25$ seconds) with acidified KHB ( $\mathrm{pH} 2.0$ ) and washed twice with $\mathrm{KHB}$ ( $\mathrm{pH}$ 7.4), and then left in the latter buffer for 5 minutes. Cells were then stimulated with hNmU-25 $(30 \mathrm{nM})$ and changes in fluorescence intensity were measured as an index of $\left[\mathrm{Ca}^{2+}\right]_{i}$ using a NOVOstar plate reader. (A) Experimental protocol. (B) Representative $\mathrm{Ca}^{2+}$ responses to hNmU-25 (30 nM) in HEK-NMU2 pre-exposed to buffer only (control) for 5 minutes or hNmU-25 (30 nM) for $1,3,5$, or 30 minutes. (C) Maximal changes in cytosolic fluorescence following the second hNmU-25 challenge. Data are mean \pm S.E.M., $n=3 ; * * P<0.01 ; * * * P<0.001$ by Bonferroni's multiple comparisons test following one-way analysis of variance. standard $\mathrm{KHB}, \mathrm{Ca}^{2+}$ responses on rechallenge with different concentrations of $\mathrm{hNmU}-25(0.1-100 \mathrm{nM})$ were assessed. In the absence of the brief acid wash to unbind ligand from receptor, functional recovery of the full intrinsic activity $\left(E_{\text {max }}\right)$ and potency $\left(\mathrm{EC}_{50}\right)$ of hNmU-25 required $\sim 300$ minutes (Fig. 5A, Table 1). In contrast, when the acid-wash procedure was applied to cells, full recovery of agonist-stimulated $\mathrm{Ca}^{2+}$ signaling occurred within approximately 120 minutes (Fig. 5B, Table 1). These data provide strong evidence that the presence of ligand bound to receptors prolonged the time required for resensitization of NMU2-mediated $\mathrm{Ca}^{2+}$ signaling.

hNmS-33 and hNmU-25 Are Equipotent, Full Agonists at NMU2, but Differ in Their Effects on Receptor Desensitization/Resensitization. $\mathrm{NmS}$ has been identified as a second endogenous ligand for NMU receptors, in particular, for those expressed centrally (Mori et al., 2005; Miyazato et al., 2008). NmS

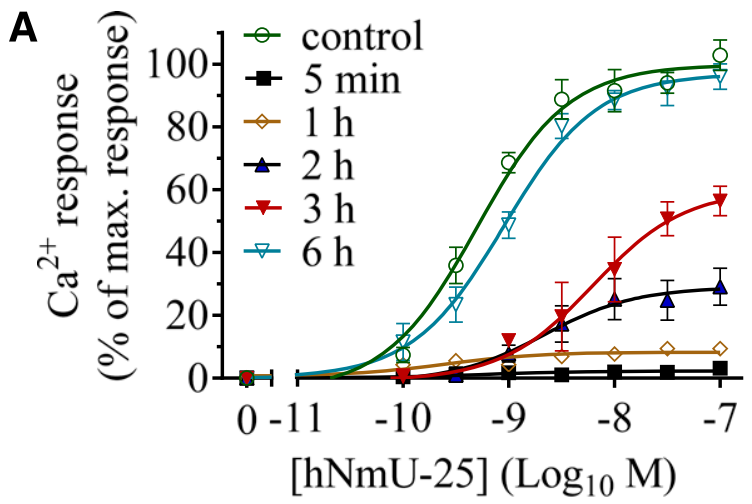

B

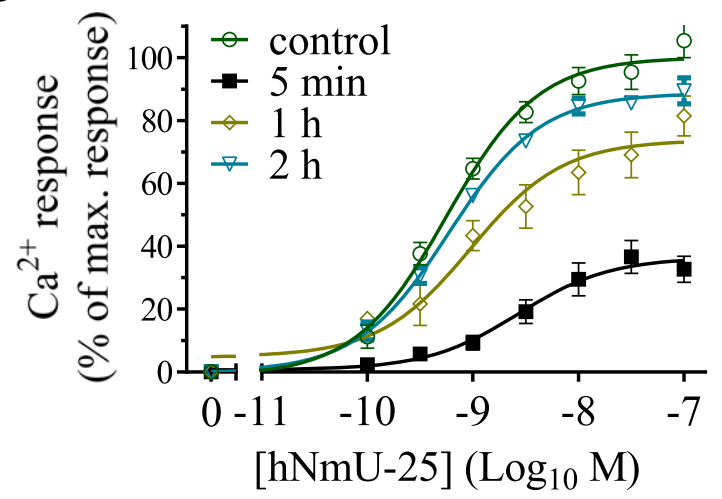

Fig. 5. Resensitization of $\mathrm{Ca}^{2+}$ responses to hNmU-25 in HEK-NMU2 following ligand removal using the standard or brief acid-wash protocol. For experiments in which a 5-minute recovery period following an initial agonist challenge was required, cells were loaded with fluo-4-AM and then challenged with either buffer (control) or hNmU-25 ( $30 \mathrm{nM}$ ) for 5 minutes. For the longer recovery periods (1-6 hours), cells were challenged and washed as previously described, but loaded with fluo-4-AM during the last 45 minutes of the recovery period. Initial agonist exposure was followed by a brief wash ( $\leq 25$ seconds) with either (A) standard KHB ( $\mathrm{pH} 7.4)$ or (B) acidified KHB ( $\mathrm{pH} 2.0$ ), followed by two washes and a 5-minute recovery period in KHB ( $\mathrm{pH}$ 7.4). Cells were subsequently rechallenged with different concentrations of hNmU-25 $(0.1-100 \mathrm{nM})$ and fluorescence was monitored using a NOVOstar plate reader. Concentration-response curves were constructed based on maximal changes in fluorescence as an index of $\left[\mathrm{Ca}^{2+}\right]_{\mathrm{i}}$ and expressed as a percentage of the maximum response in HEK-NMU2 preexposed to buffer only (i.e., no initial hNmU-25 challenge). Control concentration-response curves were generated for each time point and were not significantly different from each other. Data are mean \pm S.E.M., $n=3-6$. 
TABLE 1

Resensitization of $\mathrm{Ca}^{2+}$ responses to hNmU-25 in HEK-NMU2 following ligand washout using the standard or brief acid-wash protocol

Data are derived from the concentration-response curves shown in Fig. 5, demon strating changes in $\mathrm{pEC}_{50}$ and $E_{\max }$ values during recovery from $\mathrm{hNmU}$-25-mediated desensitization. For full details see the legend to Fig. 5 and Materials and Methods. Data are mean \pm S.E.M., $n=3-6$. ${ }^{*} P<0.05$; ${ }^{* * *} P<0.001$ vs. control by Bonferroni's multiple comparisons test, following one-way analysis of variance. Em dash (-) indicates that the experiment was not performed.

\begin{tabular}{|c|c|c|c|c|}
\hline \multirow{3}{*}{ Recovery Time } & \multicolumn{2}{|c|}{ KHB Wash (pH 7.4) } & \multicolumn{2}{|c|}{$\begin{array}{c}\text { Acidified Buffer Wash } \\
(\mathrm{pH} 2.0)\end{array}$} \\
\hline & \multirow{2}{*}{$\mathrm{pEC}_{50}$} & $E_{\max }$ & \multirow{2}{*}{$\mathrm{pEC}_{50}$} & $E_{\max }$ \\
\hline & & $\%$ & & $\%$ \\
\hline Control & $9.29 \pm 0.06$ & 100 & $9.26 \pm 0.06$ & 100 \\
\hline $5 \mathrm{~min}$ & NA & $3.1 \pm 1.1$ & $8.51 \pm 0.07^{*}$ & $32.7 \pm 4.2$ \\
\hline $1 \mathrm{~h}$ & NA & $9.4 \pm 1.7$ & $8.89 \pm 0.38$ & $81.4 \pm 6.4$ \\
\hline $2 \mathrm{~h}$ & $8.62 \pm 0.29^{*}$ & $29.1 \pm 5.9$ & $9.22 \pm 0.03$ & $89.4 \pm 4.1$ \\
\hline $3 \mathrm{~h}$ & $8.24 \pm 0.23 * * *$ & $56.4 \pm 4.7$ & - & - \\
\hline $6 \mathrm{~h}$ & $9.07 \pm 0.07$ & $96.0 \pm 4.0$ & - & - \\
\hline
\end{tabular}

NA, not applicable.

and NmU bind with similar affinity to NMU receptors, and consistent with other studies we have shown that hNmS-33 mediates $\mathrm{Ca}^{2+}$ signaling at NMU2 with equivalent maximal responses and potency to $\mathrm{hNmU}-25 \mathrm{pEC}_{50}(-\log \mathrm{M})$ values: hNmU-25, $9.18 \pm 0.05 ; \mathrm{hNmS}-33,9.30 \pm 0.10 ; n=4]$.

Here, we compared the rates of resensitization of NMU2mediated $\mathrm{Ca}^{2+}$ signaling following a 5-minute challenge with either hNmU-25 (30 $\mathrm{nM})$ or hNmS-33 (30 $\mathrm{nM})$ under conditions where free ligand, but not receptor-bound ligand, was removed by washing with $\mathrm{KHB}, \mathrm{pH}$ 7.4. Challenge of HEKNMU2 with either ligand, followed by washing and a 5-minute recovery period, resulted in equivalent and marked reductions in $\mathrm{Ca}^{2+}$ signaling (Fig. 6, A and $\mathrm{B}$ ). The time courses of recovery following the desensitization protocol were also determined for each ligand. Under these conditions, NMU2mediated $\mathrm{Ca}^{2+}$ signaling was fully restored following a 360minute recovery period after initial challenge with $\mathrm{hNmU}-25$; however, only approximately $50 \%$ of the $\mathrm{Ca}^{2+}$ response was recovered in this time period when $\mathrm{hNmS-33}$ was applied as the desensitizing stimulus (Fig. 6C).

Co-Internalization of Ligand and Receptor. Ligands that bind with high affinity are likely to be co-internalized with the receptor (Oakley et al., 2001). Here, we show that this is true for Cy3B-pNmU-8 that co-internalizes with NMU2 in a HEK cell line stably expressing C-terminally EGFP-tagged NMU2 (NMU2-EGFP) (Fig. 7A). Time courses of NMU2-EGFP were also quantified following application of hNmU-25 or hNmS-33, with the profiles of NMU2-EGFP internalization being essentially indistinguishable in extent and profile for the two ligands (Fig. 7, B and C).

Mechanistic Insights into the Resensitization of NMU2. A mechanistic understanding of the NMU2 resensitization process requires knowledge of how the ligand-receptor complex is endocytosed and processed toward recycling. The dynamin GTPase inhibitor dynasore $(80 \mu \mathrm{M})$ (Macia et al., 2006) markedly reduced resensitization of NMU2 signaling following challenge with either hNmU-25 (Fig. 8A) or hNmS33 (Fig. 8B); inhibition of endosomal acidification with either monensin (50 $\mu \mathrm{M})$ (Fig. 8, C and D) or bafilomycin A (200 nM; data not shown) also significantly reduced resensitization following challenge with either ligand. In contrast, a concentration of cycloheximide $(17.5 \mu \mathrm{M})$ that markedly reduced protein synthesis $(>80 \%$ reduction based on incorporation of
A

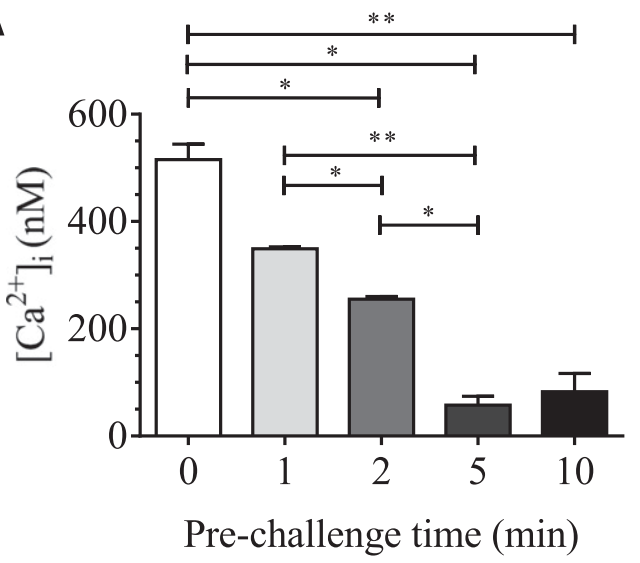

B
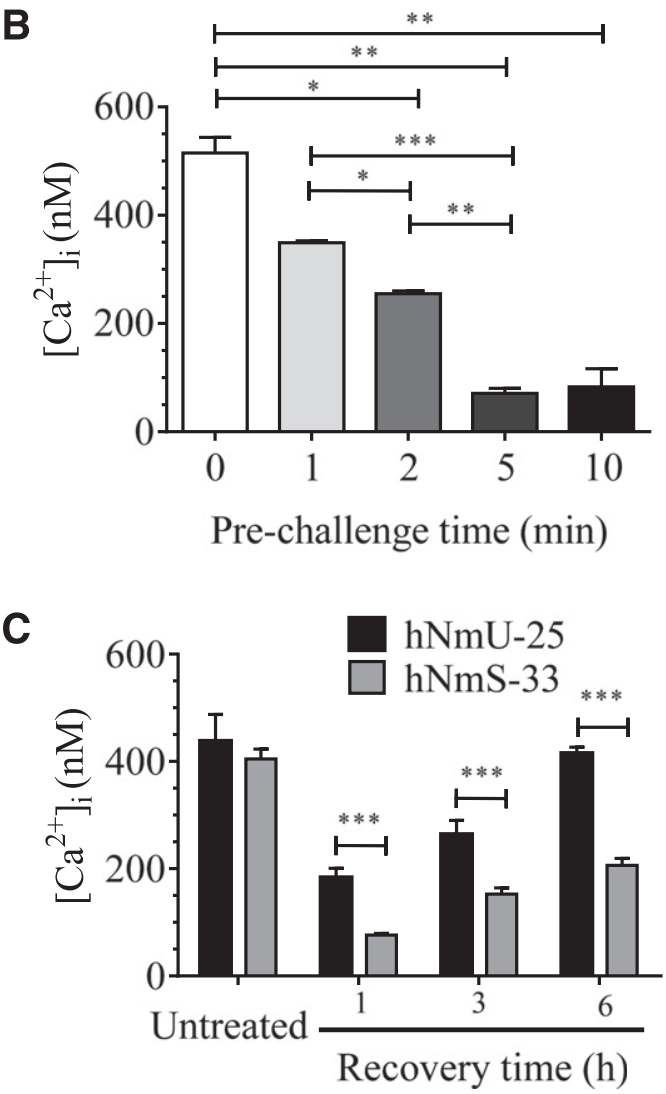

Fig. 6. Comparison of NMU2 desensitization and resensitization following challenge with hNmU-25 or hNmS-33. Fluo-4-loaded cells were either untreated (0) or pretreated with $30 \mathrm{nM}$ hNmU-25 (A) or $30 \mathrm{nM} \mathrm{hNmS-33}$ (B), and then washed with KHB ( $\mathrm{pH}$ 7.4). After a further 1-10-minute recovery period, cells were rechallenged with $30 \mathrm{nM}$ of the same ligand and $\mathrm{Ca}^{2+}$ responses were determined. Alternatively, cells were untreated or pretreated with either $30 \mathrm{nM}$ hNmU-25 or hNmS-33 for 5 minutes, and then washed and left to recover for 1, 3, or 6 hours. During the final 45 minutes of the recovery period, cells were loaded with fluo-4-AM and then rechallenged with $30 \mathrm{nM}$ ligand using a NOVOstar plate reader to allow for determination of the $\mathrm{Ca}^{2+}$ responses (C). Data are mean \pm S.E.M., $n=3 ; * P<0.05 ; * * P<0.01 ; * * * P<0.001$ by Bonferroni's multiple comparisons test, following one-way analysis of variance (A and $\mathrm{B}$ ) or unpaired Student's $t$ test (C).

$\left.{ }^{35} \mathrm{~S}\right]$-methionine into HEK cell total protein) had no significant impact on resensitization following challenge with either ligand (Fig. 8, D and E). None of these pretreatments (dynasore, monensin, or cycloheximide) affected $\mathrm{Ca}^{2+}$ responses of naive HEK-NMU2 cells to hNmU-25 or hNmS-33 


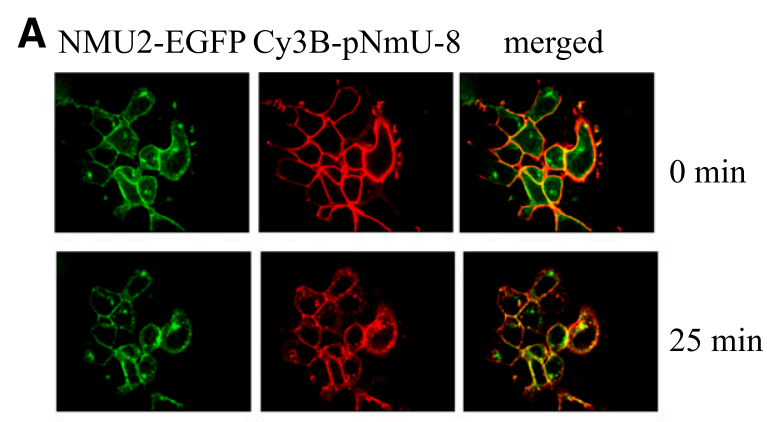

B
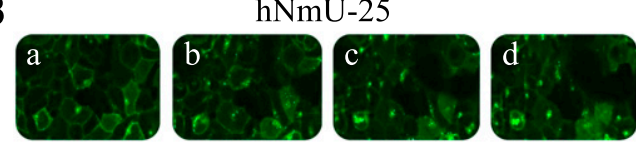

0 min

$20 \mathrm{~min}$

$60 \mathrm{~min}$

$90 \mathrm{~min}$

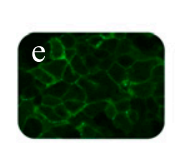

$\mathrm{hNmS}-33$
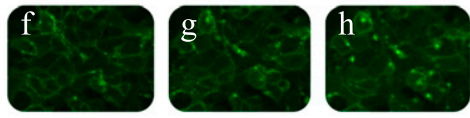

0 min

20 min

$60 \mathrm{~min}$

$90 \mathrm{~min}$

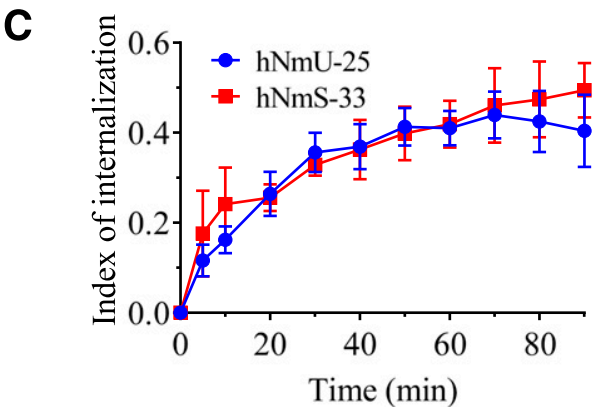

Fig. 7. Co-internalization of ligand and NMU2. HEK293 cells stably expressing NMU2 with a C-terminal EGFP tag (NMU2-EGFP) were cultured on $25 \mathrm{~mm}$ glass coverslips for 24-48 hours. Cells were challenged with $10 \mathrm{nM}$ Cy3B-pNmU-8 (A) in KHB and visualized immediately (0 minutes) or after 25 minutes (at $37^{\circ} \mathrm{C}$ ) by confocal microscopy consecutively at 488 and $568 \mathrm{~nm}$ to image NMU2-EGFP and Cy3BpNmU-8. NMU2-EGFP and Cy3B-pNmU-8 images were merged (A, right panels) postacquisition. Data are representative of three independent experiments where similar results were obtained. NMU2-EGFP was also visualized by confocal microscopy during challenge with $30 \mathrm{nM}$ of either hNmU-25 (B, images a-d) or hNmS-33 (B, images e-h). NMU2-EGFP internalization was then calculated as described in Materials and Methods and plotted as a function of time (C). Data are mean \pm S.E.M., $n=4$ to 5 cells.

(data not shown). Taken together, these data indicate that dynamin-dependent NMU2 internalization and endosomal acidification, but not de novo synthesis of NMU2, are required for resensitization of NMU2-mediated $\mathrm{Ca}^{2+}$ signaling irrespective of the agonist mediating the initial desensitization.

Role of Ligand Processing in the Resensitization of NMU2. Given that bound hNmU-25 and hNmS-33 will internalize with NMU2, we next considered if ligand processing might occur during NMU2 recycling and whether differences in the processing of $\mathrm{hNmU}-25$ and $\mathrm{hNmS}-33$ might account for differing rates of resensitization. Previous studies have shown that ECE-1 plays a role in the endosomal processing of a number of peptide ligands (Padilla et al., 2007; Roosterman et al., 2007, 2008; Law et al., 2012). Here, we explored the potential role of ECE-1 in the processing of the endogenous
NMU2 ligands using the ECE-1 inhibitor, SM-19712 (Umekawa et al., 2000). SM-19712 (10 $\mu \mathrm{M}$; 30-minute pretreatment) significantly reduced the rate of resensitization of the $\mathrm{Ca}^{2+}$ response to hNmU-25 (Fig. 9A), but was without effect on the recovery of $\mathrm{Ca}^{2+}$ signaling following challenge with hNmS-33 (Fig. 9B) in HEK-NMU2 cells. SM-19712 also had no detectable effect on the much more rapid recovery of $\mathrm{Ca}^{2+}$ responses to carbachol $(300 \mu \mathrm{M})$ following an initial activation of the endogenous $\mathrm{M}_{3}$ muscarinic acetylcholine receptors with this ligand (Fig. 9C). SM-19712 (10 or $100 \mu \mathrm{M})$ was without effect on $\mathrm{Ca}^{2+}$ responses to either $\mathrm{hNmU}-25$ or $\mathrm{hNmS}-33$ in ligand-naive cells (data not shown). The neutral endopeptidase inhibitor thiorphan $(10 \mu \mathrm{M})$ did not significantly alter resensitization time courses to either hNmU-25 or hNmS-33 (data not shown).

The ability of SM-19712 selectively to reduce the recovery of $\mathrm{Ca}^{2+}$ responses to rechallenge with $\mathrm{hNmU}-25$ might be explained by: 1) the protection of extracellular peptide from degradation (thereby potentially enhancing the extent of the initial stimulation and potential desensitization) and/or 2) the protection of intracellular peptide from degradation (thereby potentially reducing the rate of receptor recycling and subsequent resensitization). To assess these possibilities, experiments were conducted in which SM-19712 was added only after the initial stimulation and removal of free hNmU-25. When SM-19712 was added only to be present after removal of the initial challenge with hNmU-25, the extent of inhibition of resensitization was comparable to that observed when the inhibitor was added 30 minutes before the desensitizing exposure to ligand (Fig. 9D), suggesting that protection from postinternalization processing contributes to the action of this inhibitor.

Transfection of cells with siRNA against ECE-1 resulted in a significant reduction in expression (to $31 \% \pm 4 \%$ of control levels; Fig. 10A). This knockdown of expression was associated with a marked inhibition of NMU2 resensitization following prechallenge with hNmU-25 (Fig. 10B), but was without effect on the rather slower resensitization seen following prechallenge with hNmS-33 (Fig. 10C).

Ligand-Dependent Regulation of ERK and p38 MAPK Activity in HEK-NMU2. Challenge of HEK-NMU2 cells with either hNmU-25 or hNmS-33 (30 nM) resulted in time-dependent increases in pERK that remained elevated for at least 3 hours in the continued presence of ligand (Fig. 11). It was noteworthy that the pERK response to $\mathrm{hNmS}-33$ was better sustained (Fig. 11B) compared with the hNmU-25 response (Fig. 11A). Agonist-stimulated increases in pERK were concentration dependent $\left[\mathrm{pEC}_{50}(-\log \mathrm{M})\right.$ values $8.54 \pm$ 0.07 and $8.83 \pm 0.08(n=3)$ at 5 minutes for hNmU-25 and $\mathrm{hNmS}-33$, respectively]. Under these experimental conditions, where ligand was not removed, preaddition of the ECE-1 inhibitor SM-19712 $(10 \mu \mathrm{M})$ had no effect on either the magnitude or temporal profile of ERK activation stimulated by either ligand (Fig. 11).

Removal of free hNmS-33 using a buffer wash after 5 -minute stimulation resulted in a slow decline in the levels of pERK, but this was still approximately $40 \%$ of the initial response 180 minutes after removal of free, extracellular ligand (Fig. 12B). In contrast, removal of free hNmU-25 using a buffer wash after 5-minute stimulation resulted in a faster and greater loss of pERK, such that at 180 minutes after removal of free, extracellular ligand, pERK immunoreactivity had returned to basal levels (Fig. 12A). Preaddition of 
A

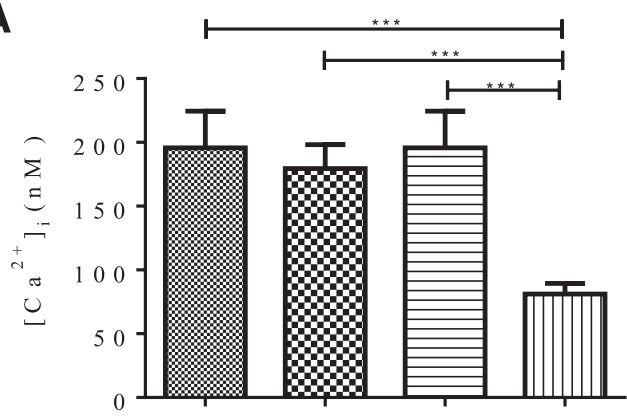

h N m U - 25

pretreatment

D y a sore

C

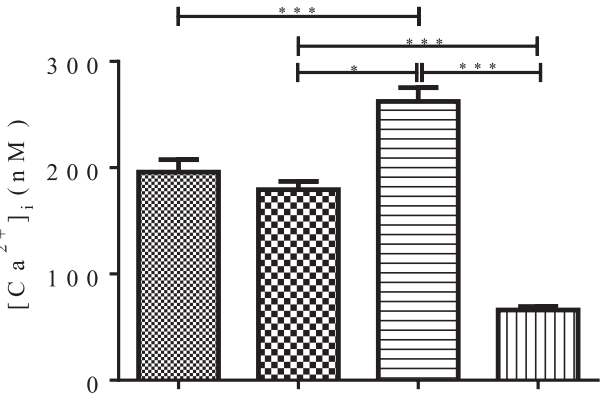

h N m U -25

pretreatment

Monensin

E

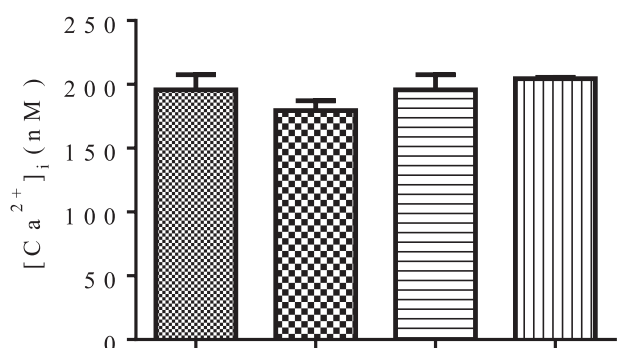

h N m U -25

pretreatment

C y clohexim ide
B

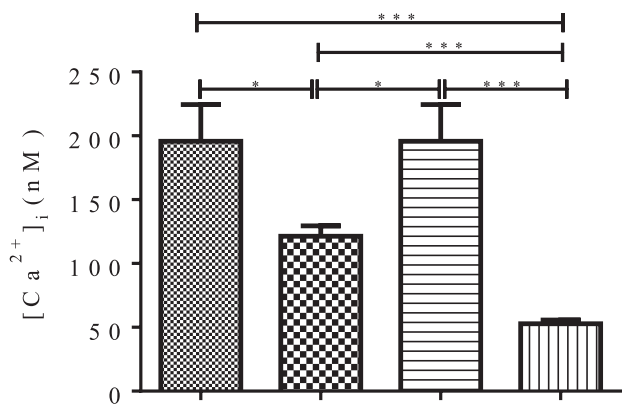

h N m S - 33

pretreatment

D ynasore

D

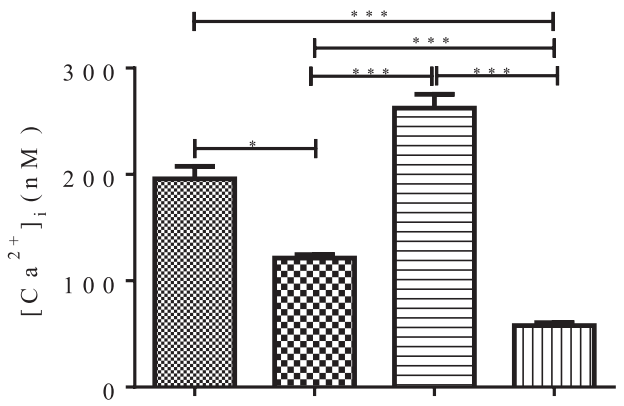

h N m S - 33

pretreatment

$M$ onensin

$\mathbf{F}$

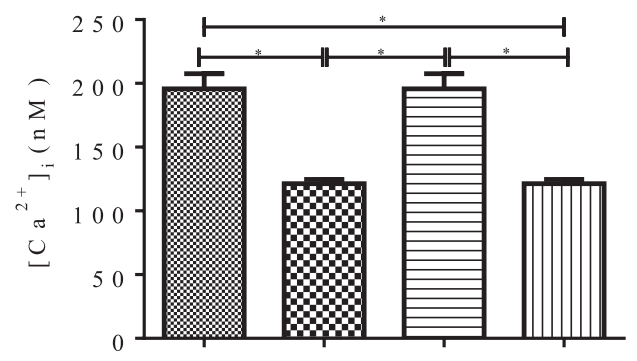

h N m S - 33

pretreatment

C ycloheximide

Fig. 8. Effects of inhibitors of receptor internalization, endosomal acidification, or protein synthesis on NMU2 resensitization following challenge with either hNmU-25 or hNmS-33. HEK-NMU2 were preincubated in the absence or presence of an inhibitor of receptor internalization (dynasore, $80 \mu \mathrm{M})(\mathrm{A}$ and $\mathrm{B}$ ), endosomal acidification (monensin, $50 \mu \mathrm{M})(\mathrm{C}$ and D), or protein synthesis (cycloheximide, $17.5 \mu \mathrm{M})(\mathrm{E}$ and $\mathrm{F})$ for 30 minutes before challenge with buffer or ligands hNmU-25 (A, C, and E) or hNmS-33 (B, D, and F), each at $30 \mathrm{nM}$ for 5 minutes). Cells were washed and allowed to recover for 6 hours ( \pm inhibitor) before determination of the $\mathrm{Ca}^{2+}$ response to the same ligand $(30 \mathrm{nM})$. Data show maximal responses following addition of ligand and are mean \pm S.E.M., $n=3 ;{ }^{*} P<0.05 ; * * P<0.01$; ${ }^{* * * P}<0.001$ by Bonferroni's multiple comparisons test, following one-way analysis of variance.

SM-19712 had no impact on the time course of the pERK response following addition and withdrawal of hNmS-33 (Fig. 12B); however, addition of this inhibitor significantly increased and prolonged the $\mathrm{pERK}$ response following addition and wash removal of hNmU-25 (Fig. 12A).

Using a similar protocol (30 $\mathrm{nM}$ ligand for 5 minutes, followed by washing to remove free, extracellular ligand) resulted in a relatively sustained increase in the levels of pp38 over the 175 minutes following ligand withdrawal with preaddition of SM-19712 having no effect on this time course (Fig. 12D). In contrast, pp38 responses to hNmU-25 declined between 25 and 175 minutes after the 5-minute agonist addition (Fig. 12C). Preaddition of SM-19712 significantly increased and prolonged the pp38 response (Fig. 12C). These 


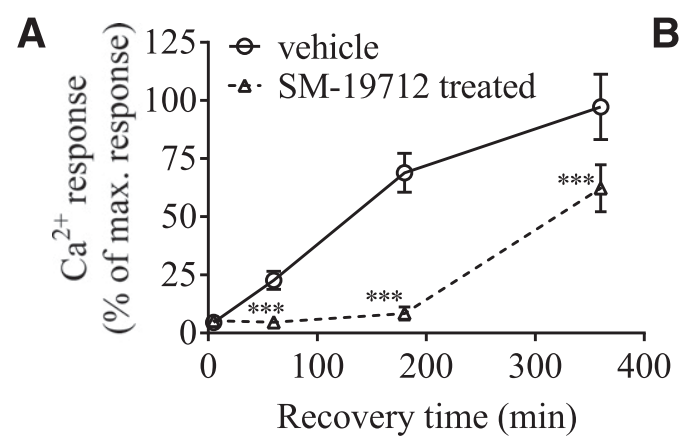

C
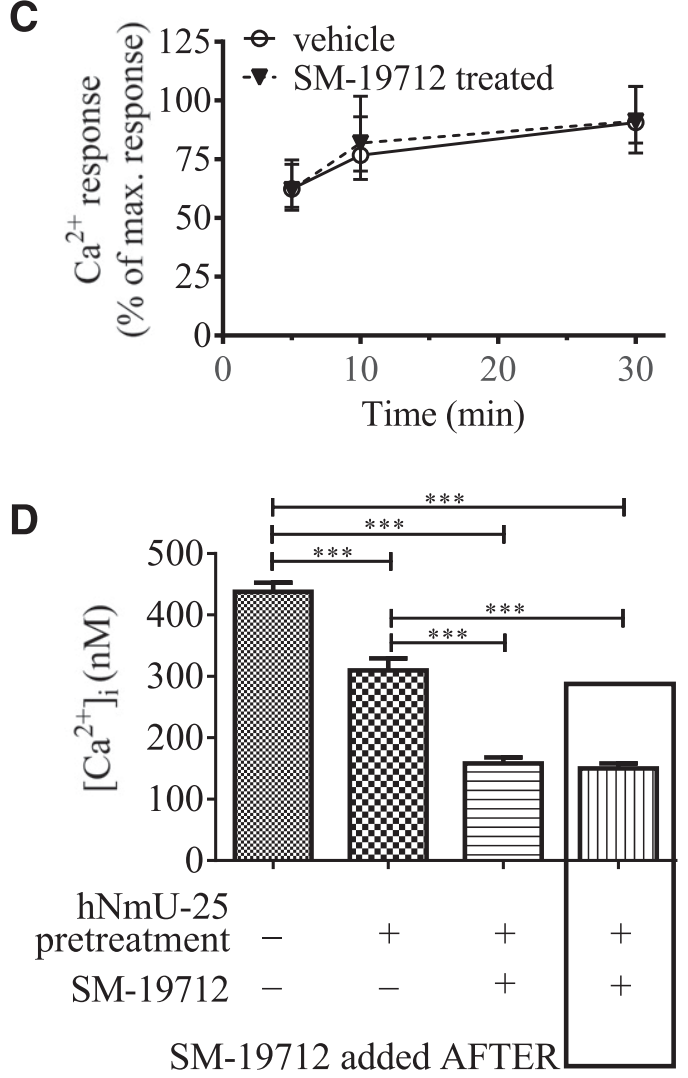

removal of hNmU-25

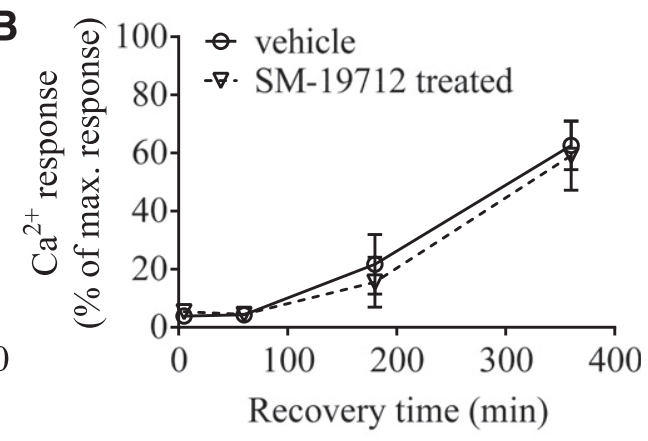

Fig. 9. Effect of the ECE-1 inhibitor, SM-19712, on NMU2 resensitization. For the 5-minute recovery protocol, cells were preincubated in the absence or presence of SM-19712 $(10 \mu \mathrm{M}$, 30 minutes) and loaded with fluo4-AM before challenge with $30 \mathrm{nM}$ hNmU-25 (A), $30 \mathrm{nM} \mathrm{hNmS-33} \mathrm{(B),}$ $100 \mu \mathrm{M}$ carbachol (C), or buffer for 5 minutes, followed by two KHB washes and a 5-minute recovery period in KHB. For longer recovery periods (1-6 hours), cells were pretreated with SM-19712 (10 $\mu \mathrm{M}, 30$ minutes) or vehicle, and then challenged with ligand or buffer and washed as previously described; during the last 45 minutes of the recovery period, cells were loaded with fluo-4-AM. Following the recovery period, cells were challenged with $30 \mathrm{nM} \mathrm{hNmU}-25$ (A), $30 \mathrm{nM}$ hNmS-33 (B), or $100 \mu \mathrm{M}$ carbachol (C), and changes in cytosolic fluorescence were recorded using a NOVOstar plate reader as an index of changes in $\left[\mathrm{Ca}^{2+}\right]_{\mathrm{i}}$. Data are expressed as a percentage of the maximum response to ligand in HEK-NMU2 challenged initially with buffer only. Alternatively, cells were challenged with buffer or hNmU-25 (30 nM, 5 minutes), washed, and allowed to recover for 3 hours in the presence or absence of SM-19712 $(10 \mu \mathrm{M})$, which was only added after ligand stimulation and washing (D). Data are mean \pm S.E. M., $n=3-6$ in duplicate; $* * * P<0.001$ by Bonferroni's multiple comparison test, following two-way analysis of variance (A) and one-way analysis of variance (D). data demonstrate that the susceptibility of hNmU-25, but not $\mathrm{hNmS}-33$, to the action of ECE-1 generates different liganddependent patterns of ERK/p38 MAPK activation.

\section{Discussion}

Our previous study established that NmU binds essentially irreversibly to NMU receptors at the plasma membrane (Brighton et al., 2004b). Such persistent agonist occupation prevents assessment of receptor desensitization that is independent of continued ligand binding and the possible sustained depletion of signaling components. Here, we used a rapid, acid-wash protocol to remove ligand, either free or bound at the cell surface, to demonstrate that NMU2 desensitization can occur independently from the continued presence of bound ligand. Indeed, the extent of desensitization is comparable to that of the $\mathrm{G} \alpha_{\mathrm{q} / 11}$-coupled $\mathrm{M}_{3}$ muscarinic receptor, which binds low-affinity small molecule ligands that are readily removed by simple wash protocols. The present data highlight the additional role played by the essentially irreversible binding of peptides to NMU2 that occurs under physiologic conditions.

The present data also demonstrate that ligand binding to NMU2 considerably lengthens the recovery time of receptormediated $\mathrm{Ca}^{2+}$ signaling. This slow resensitization is similar to that observed for a number of other peptidergic GPCRs. For example, neurokinin 1 receptor $\mathrm{Ca}^{2+}$ responses require $\sim 3$ hours to recover following challenge with substance $P$, while the CLR/RAMP1 complex needs 4-6 hours for full resensitization of CGRP-mediated $\mathrm{Ca}^{2+}$ signaling (Schmidlin et al., 2001; Padilla et al., 2007). The slower recovery of signaling following transient exposure to $\mathrm{hNmU}-25$ was markedly faster than that following an identical exposure to $\mathrm{hNmS}-33$, clearly demonstrating the critical nature of the ligand in determining the rate of resensitization. Independent of the ligand used, resensitization required receptor internalization and endosomal acidification, 
A

\section{SiRNA \\ scrambled $\mid$ ECE-1}
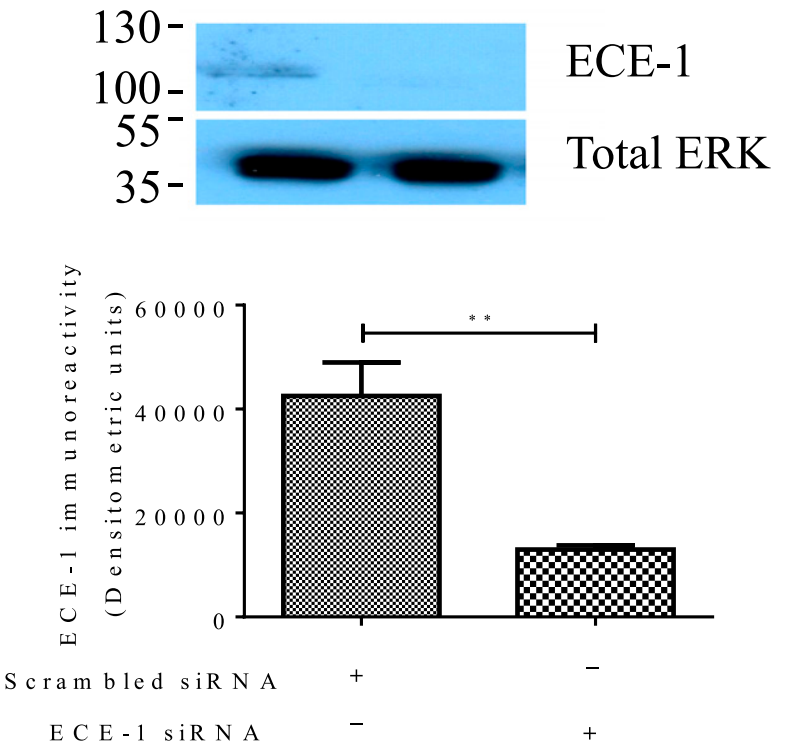

B

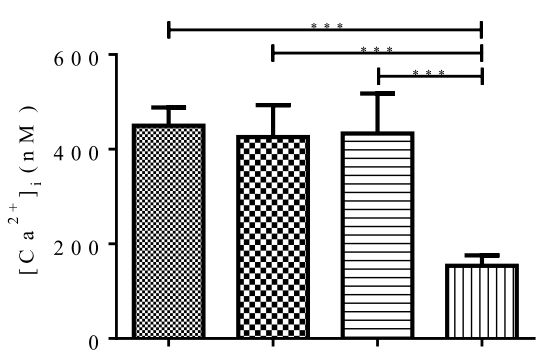

h N m U -25

pretreatm ent

E C E - 1 siR N A

E C E - 1 siR N A
C

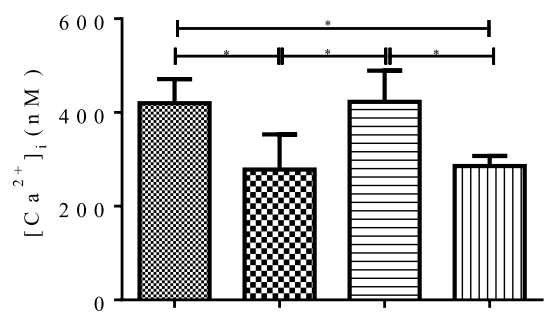

$\mathrm{hN} \mathrm{m} \mathrm{S-33}$

pretreatment but not de novo protein synthesis, which is entirely consistent with the generally accepted paradigm for GPCR trafficking following agonist activation. Thus, agonist-mediated conformational changes in the receptor result in the recruitment of $G$ protein-coupled receptor kinase isoenzymes and subsequent phosphorylation of serine/threonine residues within intracellular regions of the receptor, particularly the C-terminal tail and third intracellular loop (Pitcher et al., 1998). Such phosphorylation provides docking sites for $\beta$-arrestin, which generates steric hindrance to further $\mathrm{G}$ protein coupling, thereby initiating rapid receptor desensitization. Bound $\beta$-arrestin provides a scaffold for the internalization machinery, ultimately resulting in the removal of receptors from the cell surface into an endosomal compartment. Endosomal acidification promotes dissociation of any internalized ligand with the subsequent loss of $\beta$-arrestin binding, receptor dephosphorylation, and ultimately the recycling of receptors to the plasma membrane for further rounds of signaling (Marchese et al., 2008). The time required to fully resensitize differs among GPCRs, ranging from minutes, as for the $\beta_{2}$-adrenoceptor, to hours for some receptors including the $\mathrm{V}_{2}$ vasopressin receptor (Moore et al., 2007). Such differences are a consequence of various factors, but include the affinity for $\beta$-arrestin binding (Oakley et al., 1999; Pierce et al., 2002). With
Fig. 10. Cellular depletion of ECE-1 impairs resensitization following $\mathrm{hNmU}$ 25 but not hNmS-33 challenge. Cells were transfected with either anti-ECE-1 siRNA or a scrambled siRNA and the expression of ECE-1 was determined 48 hours later by immunoblotting. Total ERK1/2 immunoreactivity was used as a loading control (A). Cells transfected with either anti-ECE-1 siRNA (+) or scrambled siRNA (-) for 48 hours were pretreated with buffer, hNmU-25 (B), or $\mathrm{hNmS}-33$ (C) (both at $30 \mathrm{nM}$ for 5 minutes), and then washed with KHB. Cells were allowed to recover for 6 hours, loaded with fluo-4-AM during the final 45 minutes, and then challenged or rechallenged with the same concentration of each respective ligand. Changes in cytosolic fluorescence were recorded using a NOVOstar plate reader as an index of $\left[\mathrm{Ca}^{2+}\right]_{\mathrm{i}}$. Data are representative or mean \pm S.E.M., $n=3$, and were analyzed by Student's paired $t$ test (A) or Bonferroni's multiple comparisons test, following one-way analysis of variance (B and C); ${ }^{*} P<0.05$; $* * P<0.01 ; * * * P<0.001$.

respect to this, different classes of GPCRs have been identified. Type A GPCRs bind $\beta$-arrestin- 2 more favorably than $\beta$-arrestin1 , although with relatively low affinity, resulting in rapid dissociation of the receptor- $\beta$-arrestin complex at the cell surface, or directly after internalization resulting in fast recycling and resensitization (Moore et al., 2007). In contrast, type B GPCRs bind with high affinity to either $\beta$-arrestin- 1 or $\beta$-arrestin- 2 , which internalize together with the receptor to endosomes and dissociate at a slow rate, delaying recycling and resensitization (Moore et al., 2007), which is consistent with the slow resensitization of NMU2. Although little is known regarding agonistmediated phosphorylation of NMU2, the C-terminal tail contains 15 serine and threonine residues, including three pairs of serine residues that are often associated with phosphorylation and arrestin binding (Brighton et al., 2004a).

In this scheme of receptor internalization and recycling, attention rarely focuses on either the potential role or fate of the ligand. This is critical given that the presence of ligand, particularly bound to the receptor, may influence the nature and duration of $\beta$-arrestin binding. This, in turn, is of particular importance given the role of $\beta$-arrestin in scaffolding signaling complexes for both $G$ protein-dependent (Thomsen et al., 2016) and G protein-independent signaling 
A $\mathrm{hNmU}-25$
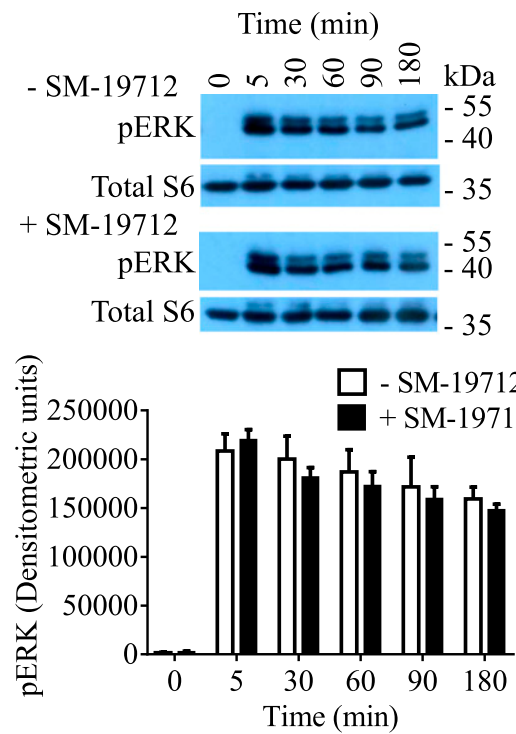

B $\mathrm{hNmS}-33$

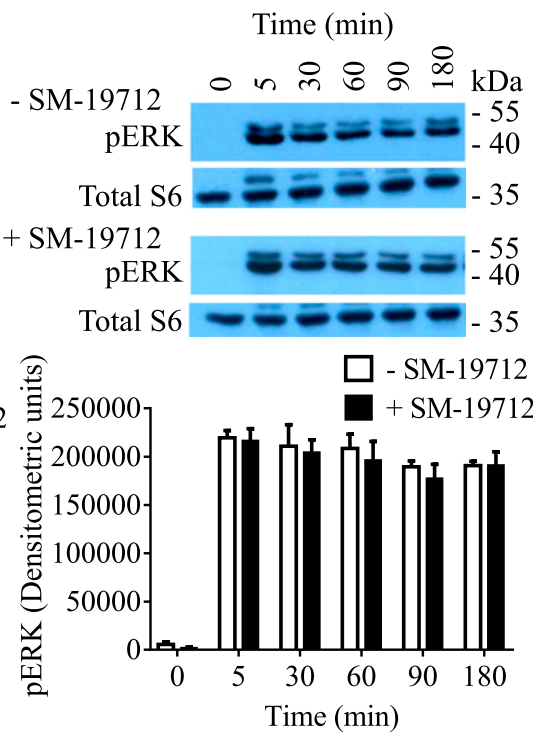

Fig. 11. Time course of NMU2-mediated activation of ERK1/2 in the presence and absence of ECE-1 inhibition in the continued presence of ligand. HEK-NMU2 cells were incubated with or without SM-19712 $(10 \mu \mathrm{M})$ for 30 minutes prior to challenge with $30 \mathrm{nM} \mathrm{hNmU-25}$ (A) or $30 \mathrm{nM} \mathrm{hNmS-}$ 33 (B). Cells were then left for the required time before solubilization and assessment of pERK by immunoblotting and densitometry. Data are representative or mean \pm S.E. M., $n=3$. Ribosomal S6 protein (total $\mathbf{S 6}$ ) is shown as a loading control. Note that pERK and total $\mathrm{S} 6$ were identified on the same blot but are shown here with different exposure times for clarity.
(DeFea, 2011; Shenoy and Lefkowitz, 2011; Luttrell and Miller, 2013) from within the cell. Given the extremely highaffinity binding of some peptide ligands and the extent of acidification that is required to drive dissociation, it is possible that some ligands retain receptor association for some time despite endosomal acidification to $\mathrm{pH}$ 4.8-6.0 (Hilal-Dandan et al., 1997; Qi et al., 2005). Although some peptide ligands may recycle to the plasma membrane intact, others are processed within the cell. Indeed, a series of important studies has highlighted a key function of such processing within the cell in defining both receptor resensitization and the duration of receptor-mediated signaling (Padilla et al., 2007; Roosterman et al., 2007, 2008; Cottrell et al., 2009; Pelayo et al., 2011; Hasdemir et al., 2012). In particular, ECE-1 is able to process a number of internalized peptide ligands to regulate receptor signaling and recycling. Although ECE-1 is best known for its ability to convert plasma big endothelin to active endothelin-1, the identification of four isoenzymes with differential subcellular distributions is consistent with alternative functions, including the degradation of peptide receptor ligands within the endosomal compartment. Interestingly, the substrate specificity of ECE-1 is $\mathrm{pH}$ dependent (Ahn et al., 1998) and the acidic $\mathrm{pH}$ of the endosomal compartment provides ideal conditions for the degradation of substance $\mathrm{P}$, calcitonin gene-related peptide, and somatostatin 14 (Poole and Bunnett, 2016). Indeed, the degradation of internalized peptide ligands within the endosomal compartment destabilizes signaling complexes and promotes recycling and resensitization of a number of receptors (Padilla et al., 2007; Roosterman et al., 2007, 2008; Cottrell et al., 2009; Pelayo et al., 2011; Hasdemir et al., 2012). More recently, sustained signaling by the neurokinin 1 receptor and calcitonin receptorlike receptor from within endosomes has been shown to be responsible for sustained neuronal activity and the transmission of pain (Jensen et al., 2017; Yarwood et al., 2017). Furthermore, targeting receptor antagonists to this compartment was demonstrated to inhibit endosomal signaling and the sustained neuronal activity highlighting novel and exciting therapeutic opportunities.
The present study demonstrates a role for ECE-1 within the cell in promoting NMU2 recycling leading to resensitization, but this is dependent on the nature of the ligand. Pharmacological inhibition of ECE-1 or knockdown with siRNA both inhibit resensitization following $\mathrm{hNmU}-25$, but not $\mathrm{hNmS}-33$, suggesting that either hNmS-33 is resistant to ECE-1 activity within the cell or that products of its degradation can continue to reduce receptor recycling. Interestingly, like NMU2, corticotropin-releasing factor receptor 1 can be activated by either of the two endogenous ligands, urocortin or the corticotrophin-releasing factor. Urocortin not only binds to corticotropin-releasing factor receptor 1 with higher affinity than the corticotrophin-releasing factor, but is also a better substrate for ECE-1, providing an explanation for the sensitivity to ECE-1 inhibition of corticotropin-releasing factor receptor 1 recycling and resensitization following urocortin, but not the corticotrophin-releasing factor (Hasdemir et al., 2012).

The present study identified different temporal profiles of ERK signaling, particularly following ligand removal. In particular, NMU2-mediated activation of ERK was more sustained following $\mathrm{hNmS-33}$ than $\mathrm{hNmU}-25$. This is consistent with a more sustained signaling complex, possibly as a consequence of the resistance of $\mathrm{hNmS}-33$ to ECE-1 proteolytic degradation and sustained $\mathrm{G}$ protein-dependent or -independent signaling. Such signaling may be from internalized receptors since NMU2 is markedly internalized. Although the removal of free extracellular ligand is clearly central to experimental studies of resensitization, this has been less commonly used when examining signaling events following a single exposure to ligand. However, such a paradigm may well reflect more accurately the type of exposure that cells are subject to in vivo. Thus, receptor ligands are more often than not released in a pulsatile or phasic manner, followed by removal by a variety of processes including dilution, extracellular degradation, and cellular uptake. Although the physiologic consequences of transient versus more sustained signaling have yet to be fully defined, the present study highlights that such considerations are critical in identifying ligand-specific 


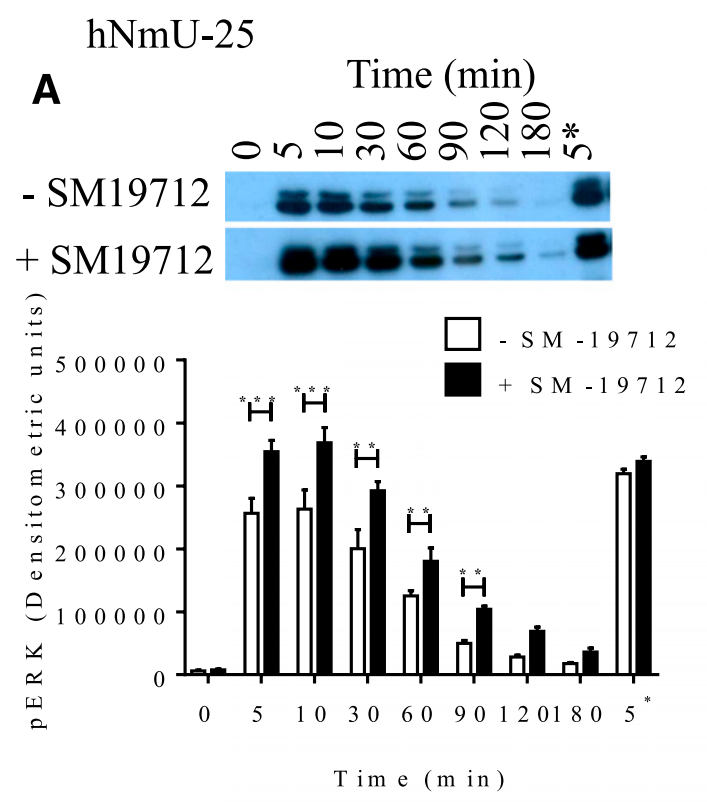

hNmU-25

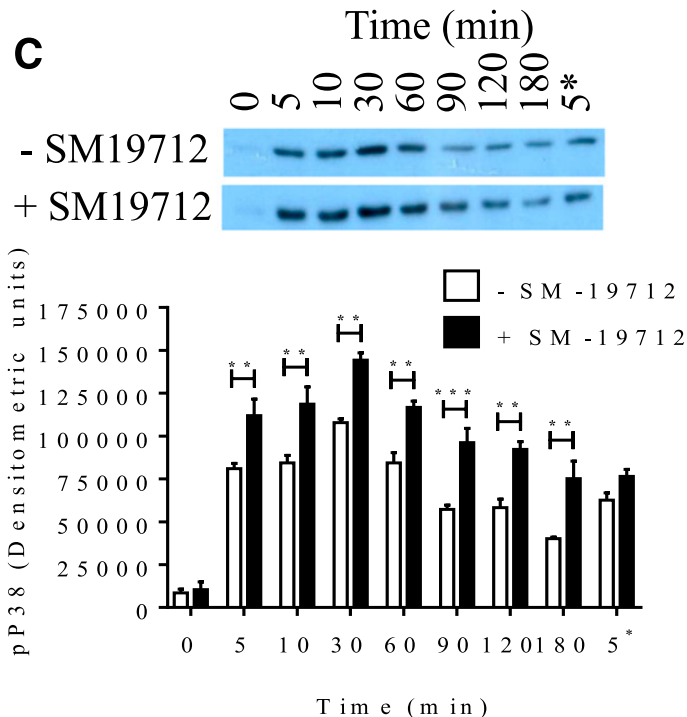

$\mathrm{hNmS}-33$

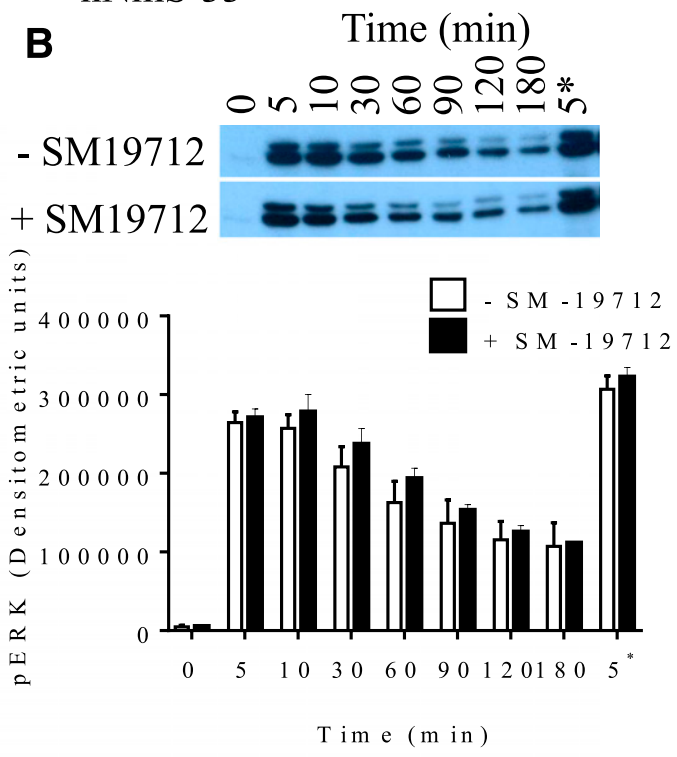

hNmS-33

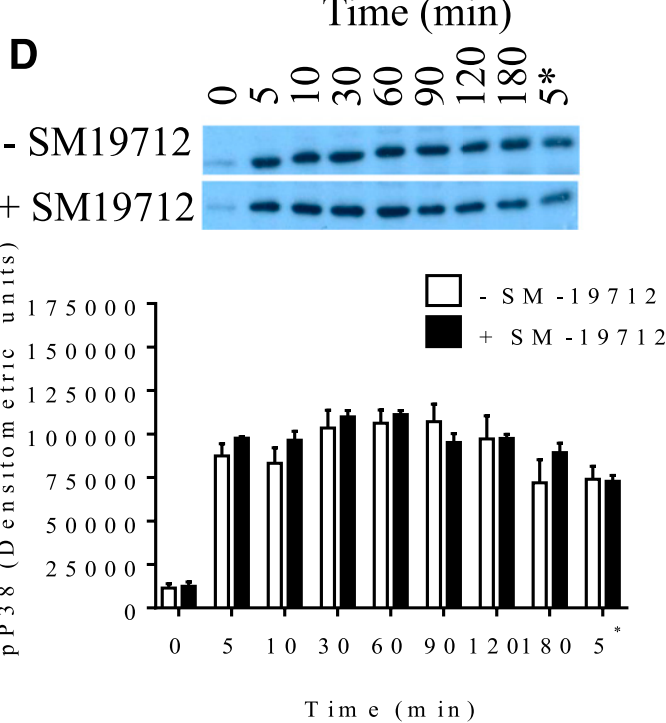

Fig. 12. Time course of NMU2-mediated activation of ERK1/2 and p38 MAPK in the presence and absence of ECE-1 inhibition following removal of free, extracellular ligand. HEK-NMU2 cells were incubated with or without SM-19712 (10 $\mu \mathrm{M})$ for 30 minutes prior to challenge with $30 \mathrm{nM}$ hNmU-25 (A and C) or $30 \mathrm{nM} \mathrm{hNmS-33} \mathrm{(B} \mathrm{and} \mathrm{D)} \mathrm{for} 5$ minutes. Free, extracellular ligand was removed by washing the monolayer twice with KHB, and then the cells were left in KHB for the required time before assessment of either pERK (A and B) or pp38 (C and D) immunoreactivity. Data are representative or mean \pm S.E. M., $n=3 ; 0$ represents the point immediately before ligand addition; $5 *$ represents the point of ligand removal; other times represent the points following ligand removal. $* * P<0.01 ; * * * P<0.001$ by Bonferroni's multiple range test, following two-way analysis of variance. Levels of ribosomal S6 protein were assessed (see Fig. 11) to ensure equivalent loading but are not shown here for clarity.

signaling profiles and ultimately, therefore, differences in biologic activity and therapeutic potential. With specific reference to ligands of NMU2, there is evidence to support the notion that signaling differences, such as those reported here, may be relevant in more physiologic settings. Thus, bolus intracerebroventricular administration of $\mathrm{NmU}$ to rats increased the neuronal electrical activity in the paraventricular nucleus between 30 and 60 minutes, whereas $\mathrm{NmS}$ increased activity for at least 120 minutes (Ida et al., 2005). This is potentially consistent with a more potent and prolonged suppression of food intake by $\mathrm{NmS}$ compared with $\mathrm{NmU}$ following intracerebroventricular administration to freely feeding rats (Ida et al., 2005; Miyazato et al., 2008). One suggestion for such differences was that $\mathrm{NmS}$ might be more resistant to proteolytic degradation than NmU. Clearly, such resistance could maintain effective extracellular concentrations of $\mathrm{NmS}$ for longer. However, the present study demonstrates an alternative possibility: that cellular signaling at NMU2 in response to $\mathrm{NmS}$ is prolonged compared with that in response to NmU. Furthermore, the data suggest that such a disparity is a consequence of differences in the intracellular processing of the two peptide ligands by intracellular, probably endosomal, ECE-1, or a similar SM-19712-sensitive protease. 


\section{Acknowledgments}

We gratefully acknowledge funding from King Saud University, Riyadh, Kingdom of Saudi Arabia (to K.A.); Tabuk University, Kingdom of Saudi Arabia (to O.B.); The Higher Committee for Education Development in Iraq; and University of Kufa, School of Medicine, Iraq (to H.Q.)

\section{Authorship Contributions}

Participated in research design: Alhosaini, Challiss, Willars.

Conducted experiments: Alhosaini, Bahattab, Qassam.

Performed data analysis: Alhosaini, Bahattab, Qassam, Challiss,

Willars.

Wrote or contributed to the writing of the manuscript: Alhosaini, Challiss, Willars.

\section{References}

Ahn K, Herman SB, and Fahnoe DC (1998) Soluble human endothelin-converting enzyme-1: expression, purification, and demonstration of pronounced $\mathrm{pH}$ sensitivity. Arch Biochem Biophys 359:258-268.

Aiyar N, Disa J, Foley JJ, Buckley PT, Wixted WE, Pullen M, Shabon U, Dul E Szekeres PG, Elshourbagy NA, et al. (2004) Radioligand binding and functional characterization of recombinant human NmU1 and NmU2 receptors stably expressed in clonal human embryonic kidney-293 cells. Pharmacology 72:33-41.

Alevizos I, Mahadevappa M, Zhang X, Ohyama H, Kohno Y, Posner M, Gallagher GT, Varvares M, Cohen D, Kim D, et al. (2001) Oral cancer in vivo gene expression profiling assisted by laser capture microdissection and microarray analysis. Oncogene 20:6196-6204.

Brighton PJ, Szekeres PG, and Willars GB (2004a) Neuromedin U and its receptors: structure, function, and physiological roles. Pharmacol Rev 56:231-248.

Brighton PJ, Szekeres PG, Wise A, and Willars GB (2004b) Signaling and ligand binding by recombinant neuromedin $\mathrm{U}$ receptors: evidence for dual coupling to $\mathrm{G} \alpha_{\mathrm{q}}$ 11 and $\mathrm{G} \alpha_{\mathrm{i}}$ and an irreversible ligand-receptor interaction. Mol Pharmacol 66: $1544-1556$.

Brighton PJ, Wise A, Dass NB, and Willars GB (2008) Paradoxical behavior of neuromedin $\mathrm{U}$ in isolated smooth muscle cells and intact tissue. J Pharmacol Exp Ther 325:154-164

Cottrell GS, Padilla BE, Amadesi S, Poole DP, Murphy JE, Hardt M, Roosterman D, Steinhoff M, and Bunnett NW (2009) Endosomal endothelin-converting enzyme-1: a regulator of $\beta$-arrestin-dependent ERK signaling. J Biol Chem 284:22411-22425.

DeFea KA (2011) Beta-arrestins as regulators of signal termination and transduction: how do they determine what to scaffold? Cell Signal 23:621-629.

Hanada R, Teranishi H, Pearson JT, Kurokawa M, Hosoda H, Fukushima N, Fukue Y, Serino R, Fujihara H, Ueta Y, et al. (2004) Neuromedin U has a novel anorexigenic effect independent of the leptin signaling pathway. Nat Med 10:1067-1073.

Harten SK, Esteban MA, Shukla D, Ashcroft M, and Maxwell PH (2011) Inactivation of the von Hippel-Lindau tumour suppressor gene induces neuromedin U expression in renal cancer cells. Mol Cancer 10:89.

Hasdemir B, Mahajan S, Bunnett NW, Liao M, and Bhargava A (2012) Endothelinconverting enzyme-1 actions determine differential trafficking and signaling of corticotropin-releasing factor receptor 1 at high agonist concentrations. Mol Endocrinol 26:681-695.

Hilal-Dandan R, Villegas S, Gonzalez A, and Brunton LL (1997) The quasiirreversible nature of endothelin binding and $\mathrm{G}$ protein-linked signaling in cardiac myocytes. J Pharmacol Exp Ther 281:267-273.

Hosoya M, Moriya T, Kawamata Y, Ohkubo S, Fujii R, Matsui H, Shintani Y, Fukusumi S, Habata Y, Hinuma S, et al. (2000) Identification and functional characterization of a novel subtype of neuromedin U receptor. J Biol Chem $\mathbf{2 7 5}$ : 29528-29532.

Howard AD, Wang R, Pong SS, Mellin TN, Strack A, Guan XM, Zeng Z, Williams DL, Jr, Feighner SD, Nunes CN, et al. (2000) Identification of receptors for neuromedin $\mathrm{U}$ and its role in feeding. Nature 406:70-74.

Ida T, Mori K, Miyazato M, Egi Y, Abe S, Nakahara K, Nishihara M, Kangawa K, and Murakami N (2005) Neuromedin S is a novel anorexigenic hormone. Endocrinology 146:4217-4223.

Jensen DD, Lieu T, Halls ML, Veldhuis NA, Imlach WL, Mai QN, Poole DP, Quach T, Aurelio L, Conner J, et al. (2017) Neurokinin 1 receptor signaling in endosomes mediates sustained nociception and is a viable therapeutic target for prolonged pain relief. Sci Transl Med 9:eaal3447.

Johnson EN, Appelbaum ER, Carpenter DC, Cox RF, Disa J, Foley JJ, Ghosh SK, Naselsky DP, Pullen MA, Sarau HM, et al. (2004) Neuromedin U elicits cytokine release in murine Th2-type T cell clone D10.G4.1. J Immunol 173:7230-7238.

Kaczmarek P, Malendowicz LK, Pruszynska-Oszmalek E, Wojciechowicz T, Szczepankiewicz D, Szkudelski T, and Nowak KW (2006) Neuromedin U receptor 1 expression in the rat endocrine pancreas and evidence suggesting neuromedin U suppressive effect on insulin secretion from isolated rat pancreatic islets. Int J Mol Med 18:951-955.

Kojima M, Haruno R, Nakazato M, Date Y, Murakami N, Hanada R, Matsuo H, and Kangawa K (2000) Purification and identification of neuromedin U as an endogenous ligand for an orphan receptor GPR66 (FM3). Biochem Biophys Res Commun 276:435-438.

Law IK, Murphy JE, Bakirtzi K, Bunnett NW, and Pothoulakis C (2012) Neurotensin-induced proinflammatory signaling in human colonocytes is regulated by $\beta$-arrestins and endothelin-converting enzyme-1-dependent endocytosis and resensitization of neurotensin receptor 1. J Biol Chem 287:15066-15075.
Luttrell LM and Miller WE (2013) Arrestins as regulators of kinases and phosphatases. Prog Mol Biol Transl Sci 118:115-147.

Macia E, Ehrlich M, Massol R, Boucrot E, Brunner C, and Kirchhausen T (2006) Dynasore, a cell-permeable inhibitor of dynamin. Dev Cell 10:839-850.

Malendowicz LK, Ziolkowska A, and Rucinski M (2012) Neuromedins U and S in volvement in the regulation of the hypothalamo-pituitary-adrenal axis. Front Endocrinol (Lausanne) 3:156.

Marchese A, Paing MM, Temple BR, and Trejo J (2008) G protein-coupled receptor sorting to endosomes and lysosomes. Annu Rev Pharmacol Toxicol 48:601-629.

Mitchell JD, Maguire JJ, and Davenport AP (2009a) Emerging pharmacology and physiology of neuromedin $\mathrm{U}$ and the structurally related peptide neuromedin $\mathrm{S}$. $\mathrm{Br}$ $J$ Pharmacol 158:87-103.

Mitchell JD, Maguire JJ, Kuc RE, and Davenport AP (2009b) Expression and vasoconstrictor function of anorexigenic peptides neuromedin U-25 and S in the human cardiovascular system. Cardiovasc Res 81:353-361.

Miyazato M, Mori K, Ida T, Kojima M, Murakami N, and Kangawa K (2008) Identification and functional analysis of a novel ligand for G protein-coupled receptor, Neuromedin S. Regul Pept 145:37-41.

Moore CA, Milano SK, and Benovic JL (2007) Regulation of receptor trafficking by GRKs and arrestins. Annu Rev Physiol 69:451-482.

Mori K, Miyazato M, Ida T, Murakami N, Serino R, Ueta Y, Kojima M, and Kangawa $\mathrm{K}$ (2005) Identification of neuromedin $\mathrm{S}$ and its possible role in the mammalian circadian oscillator system. EMBO J 24:325-335.

Moriyama M, Fukuyama S, Inoue H, Matsumoto T, Sato T, Tanaka K, Kinjyo I, Kano T, Yoshimura A and Kojima M (2006a) The neuropeptide neuromedin U activates eosinophils and is involved in allergen-induced eosinophilia. Am J Physiol Lung Cell Mol Physiol 290:L971-L977.

Moriyama M, Matsukawa A, Kudoh S, Takahashi T, Sato T, Kano T, Yoshimura A and Kojima M (2006b) The neuropeptide neuromedin U promotes IL-6 production from macrophages and endotoxin shock. Biochem Biophys Res Commun 341: $1149-1154$

Moriyama M, Sato T, Inoue H, Fukuyama S, Teranishi H, Kangawa K, Kano T, Yoshimura A, and Kojima M (2005) The neuropeptide neuromedin U promotes inflammation by direct activation of mast cells. J Exp Med 202:217-224.

Nakahara K, Katayama T, Maruyama K, Ida T, Mori K, Miyazato M, Kangawa K, and Murakami N (2010) Comparison of feeding suppression by the anorexigenic hormones neuromedin $U$ and neuromedin $\mathrm{S}$ in rats. J Endocrinol 207:185-193.

Oakley RH, Laporte SA, Holt JA, Barak LS, and Caron MG (1999) Association of $\beta$-arrestin with $\mathrm{G}$ protein-coupled receptors during clathrin-mediated endocytosis dictates the profile of receptor resensitization. J Biol Chem 274:32248-32257.

Oakley RH, Laporte SA, Holt JA, Barak LS, and Caron MG (2001) Molecular determinants underlying the formation of stable intracellular $\mathrm{G}$ protein-coupled receptor- $\beta$-arrestin complexes after receptor endocytosis*. J Biol Chem 276: 19452-19460.

Padilla BE, Cottrell GS, Roosterman D, Pikios S, Muller L, Steinhoff M, and Bunnett NW (2007) Endothelin-converting enzyme-1 regulates endosomal sorting of calcitonin receptor-like receptor and $\beta$-arrestins. J Cell Biol 179:981-997.

Peier AM, Desai K, Hubert J, Du X, Yang L, Qian Y, Kosinski JR, Metzger JM, Pocai A, Nawrocki AR, et al. (2011) Effects of peripherally administered neuromedin U on energy and glucose homeostasis. Endocrinology 152:2644-2654.

Pelayo JC, Poole DP, Steinhoff M, Cottrell GS, and Bunnett NW (2011) Endothelinconverting enzyme-1 regulates trafficking and signalling of the neurokinin 1 receptor in endosomes of myenteric neurones. J Physiol 589:5213-5230.

Pierce KL, Premont RT, and Lefkowitz RJ (2002) Seven-transmembrane receptors. Nat Rev Mol Cell Biol 3:639-650.

Pitcher JA, Freedman NJ, and Lefkowitz RJ (1998) G protein-coupled receptor kinases. Annu Rev Biochem 67:653-692.

Poole DP and Bunnett NW (2016) G protein-coupled receptor trafficking and signalling in the enteric nervous system: the past, present and future. Adv Exp Med Biol 891:145-152.

Prendergast CE, Morton MF, Figueroa KW, Wu X, and Shankley NP (2006) Speciesdependent smooth muscle contraction to Neuromedin $U$ and determination of the receptor subtypes mediating contraction using NMU1 receptor knockout mice. $\mathrm{Br} J$ Pharmacol 147:886-896.

Qi JS, Minor LK, Smith C, Hu B, Yang J, Andrade-Gordon P, and Damiano B (2005) Characterization of functional urotensin II receptors in human skeletal muscle myoblasts: comparison with angiotensin II receptors. Peptides 26:683-690.

Raddatz R, Wilson AE, Artymyshyn R, Bonini JA, Borowsky B, Boteju LW, Zhou S, Kouranova EV, Nagorny R, Guevarra MS, et al. (2000) Identification and characterization of two neuromedin $U$ receptors differentially expressed in peripheral tissues and the central nervous system. J Biol Chem 275:32452-32459.

Rani S, Corcoran C, Shiels L, Germano S, Breslin S, Madden S, McDermott MS, Browne BC, O'Donovan N, Crown J, et al. (2014) Neuromedin U: a candidate biomarker and therapeutic target to predict and overcome resistance to HERtyrosine kinase inhibitors. Cancer Res 74:3821-3833.

Roosterman D, Cottrell GS, Padilla BE, Muller L, Eckman CB, Bunnett NW, and Steinhoff M (2007) Endothelin-converting enzyme 1 degrades neuropeptides in endosomes to control receptor recycling. Proc Natl Acad Sci USA 104 $11838-11843$.

Roosterman D, Kempkes C, Cottrell GS, Padilla BE, Bunnett NW, Turck CW, and Steinhoff M (2008) Endothelin-converting enzyme-1 degrades internalized somatostatin-14. Endocrinology 149:2200-2207.

Schmidlin F, Dery O, DeFea KO, Slice L, Patierno S, Sternini C, Grady EF, and Bunnett NW (2001) Dynamin and Rab5a-dependent trafficking and signaling of the neurokinin 1 receptor. J Biol Chem 276:25427-25437.

Shan L, Qiao X, Crona JH, Behan J, Wang S, Laz T, Bayne M, Gustafson EL, Monsma FJ, Jr, and Hedrick JA (2000) Identification of a novel neuromedin U receptor subtype expressed in the central nervous system. J Biol Chem 275: 39482-39486.

Shenoy SK and Lefkowitz RJ (2011) $\beta$-Arrestin-mediated receptor trafficking and signal transduction. Trends Pharmacol Sci 32:521-533. 
Shetzline SE, Rallapalli R, Dowd KJ, Zou S, Nakata Y, Swider CR, Kalota A, Choi JK, and Gewirtz AM (2004) Neuromedin U: a Myb-regulated autocrine growth factor for human myeloid leukemias. Blood 104:1833-1840.

Stott LA, Hall DA, and Holliday ND (2016) Unravelling intrinsic efficacy and ligand bias at G protein coupled receptors: a practical guide to assessing functional data. Biochem Pharmacol 101:1-12.

Szekeres PG, Muir AI, Spinage LD, Miller JE, Butler SI, Smith A, Rennie GI, Murdock PR, Fitzgerald LR, Wu Hl, et al. (2000) Neuromedin U is a potent agonist at the orphan G protein-coupled receptor FM3. J Biol Chem 275:20247-20250.

Thompson GL, Lane JR, Coudrat T, Sexton PM, Christopoulos A, and Canals M (2015) Biased agonism of endogenous opioid peptides at the $\mu$-opioid receptor. $\mathrm{Mol}$ Pharmacol 88:335-346.

Thomsen ARB, Plouffe B, Cahill TJ, III, Shukla AK, Tarrasch JT, Dosey AM, Kahsai AW, Strachan RT, Pani B, Mahoney JP, et al. (2016) GPCR-G protein$\beta$-arrestin super-complex mediates sustained $\mathrm{G}$ protein signaling. Cell 166 907-919.
Umekawa K, Hasegawa H, Tsutsumi Y, Sato K, Matsumura Y, and Ohashi N (2000) Pharmacological characterization of a novel sulfonylureid-pyrazole derivative, SM-19712, a potent nonpeptidic inhibitor of endothelin converting enzyme. Jpn J Pharmacol 84:7-15.

Yamasaki-Mann M, Demuro A, and Parker I (2009) cADPR stimulates SERCA activity in Xenopus oocytes. Cell Calcium 45:293-299.

Yarwood RE, Imlach WL, Lieu T, Veldhuis NA, Jensen DD, Klein Herenbrink C, Aurelio L, Cai Z, Christie MJ, Poole DP, et al. (2017) Endosomal signaling of the receptor for calcitonin gene-related peptide mediates pain transmission. Proc Natl Acad Sci USA 114:12309-12314.

Address correspondence to: Dr. Gary B. Willars, Department of Molecular and Cell Biology, University of Leicester, University Road, Leicester, LE1 7RH, United Kingdom. E-mail: gbw2@le.ac.uk 